\title{
A Cycloaddition Cascade Approach to the Total Synthesis of (-)FR182877
}

\author{
David A. Evans* and Jeremy T. Starr \\ Department of Chemistry and Chemical Biology, Harvard University, Massachusetts 02138
}

\section{Supporting Information}

\section{Evans@chemistry.harvard.edu}

Experimental Procedures. All reactions were carried out under an atmosphere of argon in flame-dried glassware. The reaction solvents: THF, $\mathrm{Et}_{2} \mathrm{O}, \mathrm{CH}_{2} \mathrm{Cl}_{2}$ were purified by passage over activated alumina. Reagents were used as received from the manufacturer unless otherwise stated. Flash chromatography was carried out using EM reagent silica gel 60 (230-400 mesh). Analytical thin layer chromatography was performed on EM Reagent $0.25 \mathrm{~mm}$ silica gel $60-\mathrm{F}$ plates. All TLC plates were visualized by UV fluorescence quenching and were stained with either p-anisaldehyde or ceric ammonium molybdate (CAM). Optical rotations were measured on a Jasco DIP-0181 digital polarimeter with a sodium lamp and are reported as follows: $[\alpha]_{\lambda}^{\mathrm{T}^{\circ} \mathrm{C}}$ $(\mathrm{c}=\mathrm{g} / 100 \mathrm{~mL}$ solvent). Infrared spectra were recorded on a Perkin-Elmer 1600 series FT-IR spectrometer. ${ }^{1} \mathrm{H}-\mathrm{NMR}$ spectra were recorded on a Varian Inova-500 (500 MHz) spectrometer and are reported in ppm using solvent as an internal standard $\left(\mathrm{CDCl}_{3}=7.26 \mathrm{ppm}\right)$. Data are reported as: [ $\delta$ shift $]([\mathrm{s}=$ singlet, $\mathrm{d}=$ doublet, $\mathrm{t}=$ triplet, $\mathrm{q}=$ quartet, $\mathrm{m}=$ multiplet, $\mathrm{b}=\mathrm{broad}]$, [integration], and $[\mathrm{J}=$ coupling constant in $\mathrm{Hz}])$. Proton decoupled ${ }^{13} \mathrm{C}-\mathrm{NMR}$ spectra were recorded on a Varian Mercury $400(100 \mathrm{MHz})$ spectrometer and are reported in ppm using solvent as internal standard $\left(\mathrm{CDCl}_{3}=77.0 \mathrm{ppm}\right)$. Low and high resolution mass spectra were obtained at the Harvard University Mass Spectrometry Laboratory.

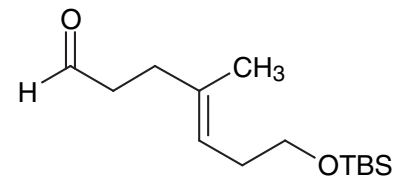

(4E)-4-methyl-7-(1,1,2,2-tetramethyl-1-silapropoxy)hept-4-enal (8). To a solution of TBSCl $(24.0 \mathrm{~g}, 159 \mathrm{mmol})$ in $100 \mathrm{~mL}$ of DMF at $0{ }^{\circ} \mathrm{C}$ under argon was added imidazole (17.3 g, $254 \mathrm{mmol})$ followed by 3butenol (10.3 g, $143 \mathrm{mmol})$. The reaction was warmed to $\mathrm{rt}$ and stirred for $24 \mathrm{~h}$ during which time the product, 1-tert-butyldimethylsilyloxy-3-butene (6), formed an immiscible layer on top of the reaction. The top layer was collected and the DMF layer was poured onto $300 \mathrm{~mL}$ of water and extracted with $3 \times 100 \mathrm{~mL}$ of pentane. The combined organic layers were washed with $1 \times 50 \mathrm{~mL} 10 \%$ aq $\mathrm{CuSO}_{4}, 3 \times 100 \mathrm{~mL}$ of water, $1 \times 100 \mathrm{~mL}$ of brine then dried over $\mathrm{Na}_{2} \mathrm{SO}_{4}$. Concentration in vacuo yielded $24.0 \mathrm{~g}$ (90\%) of 1-tertbutyldimethylsilyloxy-3-butene (7) as a colorless oil that was used without purification.

Into a solution of 1-tert-butyldimethylsilyloxy-3-butene (7) $(24.0 \mathrm{~g}, 129 \mathrm{mmol})$ in $200 \mathrm{~mL}$ of $\mathrm{CH}_{2} \mathrm{Cl}_{2}$ and $50 \mathrm{~mL}$ of $\mathrm{MeOH}$ at $-78{ }^{\circ} \mathrm{C}$ was passed a dilute stream of $\mathrm{O}_{3}$ in $\mathrm{O}_{2}$ until the reaction achieved a persistent blue color. Triphenylphosphine (33.8 g, $129 \mathrm{mmol})$ was then added and the reaction was warmed to $\mathrm{rt}$ under argon and stirred for $6 \mathrm{~h}$. The mixture was then concentrated in vacuo to give a slurry of white precipitate and oil which was resuspended in $300 \mathrm{~mL}$ of hexanes and filtered. The filter cake was washed with $3 \times 50 \mathrm{~mL}$ of hexanes and the combined filtrates were concentrated in vacuo. The resulting oil was distilled (23 torr, $\left.90-95^{\circ} \mathrm{C}\right)$ to give $19.9 \mathrm{~g}$ (83\%) of pure 3-tert-butyldimethylsilyloxy-propanal.

To a solution of isopropenylmagnesium bromide $(80 \mathrm{~mL}, 1.0 \mathrm{M}, 80 \mathrm{mmol})$ at $0{ }^{\circ} \mathrm{C}$ under argon was added 3-tert-butyldimethylsilyloxy-propanal $(8.28 \mathrm{~g}, 43.9 \mathrm{mmol})$ dropwise. The reaction was immediately poured onto $100 \mathrm{~mL}$ of sat aq $\mathrm{NH}_{4} \mathrm{Cl}$ and extracted with $3 \times 100 \mathrm{~mL}$ of $\mathrm{Et}_{2} \mathrm{O}$. 
The combined organic layers were washed with $1 \times 100 \mathrm{~mL}$ of brine then dried over $\mathrm{Na}_{2} \mathrm{SO}_{4}$. Solvent removal in vacuo gave a quantitative return of unpurified (+/-)-5-tertbutyldimethylsilyloxy-2-methyl-1-penten-3-ol as a colorless oil. This oil was dissolved in 50 $\mathrm{mL}$ of freshly distilled triethylorthoacetate and propionic acid $(0.02 \mathrm{~mL})$ was added. The solution was heated at reflux for $1 \mathrm{~h}$ then the solvent was directly distilled off the reaction under vacuum (50 torr). The residue was purified by silica gel chromatography (20:1 hexanes / EtOAc) to give $9.86 \mathrm{~g}$ (75\% 2 steps) of ethyl 7-tert-butyldimethylsilyloxy-4-methyl-trans-4heptenoate as a colorless oil. To a solution of ethyl 7-tert-butyldimethylsilyloxy-4-methyl-trans4-heptenoate (8.88 g, $29.5 \mathrm{mmol}$ ) in $50 \mathrm{~mL}$ of $\mathrm{CH}_{2} \mathrm{Cl}_{2}$ at $-78{ }^{\circ} \mathrm{C}$ under argon was added DIBAL (29.5 mL, $1.0 \mathrm{M}$ in $\mathrm{CH}_{2} \mathrm{Cl}_{2}, 29.5 \mathrm{mmol}$ ) dropwise while maintaining the internal temperature at below $-65{ }^{\circ} \mathrm{C}$. The reaction was quenched by the addition of $0.1 \mathrm{~mL}$ of EtOAc then $50 \mathrm{~mL}$ of sat aq $\mathrm{Na} / \mathrm{K}$ tartrate was added and the slurry was stirred vigorously at $\mathrm{rt}$ for $12 \mathrm{~h}$. The resulting clear biphase was extracted with $3 \times 100 \mathrm{~mL}$ of $\mathrm{CH}_{2} \mathrm{Cl}_{2}$ and the combined organic layers were washed with $1 \times 100 \mathrm{~mL}$ of brine then dried over $\mathrm{Na}_{2} \mathrm{SO}_{4}$. Concentration in vacuo yielded a colorless oil that was purified by silica gel chromatography $\left(20: 1\right.$ pentane / $\left.\mathrm{Et}_{2} \mathrm{O}\right)$ to give $7.37 \mathrm{~g}$ $(97 \%)$ of aldehyde 8 as a colorless pungent oil. $\mathbf{R}_{\mathbf{f}}: 0.25$ (9:1 hexanes / $\left.\mathrm{Et}_{2} \mathrm{O}\right){ }^{\mathbf{1}} \mathbf{H}$-NMR (500 $\left.\mathrm{MHz} \mathrm{CDCl}_{3}\right) \delta 9.76(\mathrm{~s}, 1 \mathrm{H}), 5.18(\mathrm{t}, 1 \mathrm{H}, J=7.6 \mathrm{~Hz}), 3.57(\mathrm{t}, 2 \mathrm{H}, J=7.3 \mathrm{~Hz}), 2.52(\mathrm{t}, 2 \mathrm{H}, J=7.3$ $\mathrm{Hz}), 2.33(\mathrm{t}, 2 \mathrm{H}, J=7.3 \mathrm{~Hz}), 2.22(\mathrm{q}, 2 \mathrm{H}, J=6.8 \mathrm{~Hz}), 1.64(\mathrm{~s}, 3 \mathrm{H}), 0.89(\mathrm{~s}, 9 \mathrm{H}), 0.05(\mathrm{~s}, 6 \mathrm{H}){ }^{13} \mathrm{C}-$ NMR $\left(100 \mathrm{MHz}, \mathrm{CDCl}_{3}\right) \delta 202.38,134.79,121.53,62.75,42.01,31.74,31.66,25.86,18.25$, 16.15, -5.35 FTIR $v$ 2929, 2858, 1727, 1472, 1255, 1096, 938, 835, 775 HRMS (FAB) Calc'd for $\mathrm{C}_{14} \mathrm{H}_{28} \mathrm{O}_{2} \mathrm{Si}[\mathrm{M}+\mathrm{Na}]$ : 274.2202; found 274.2197

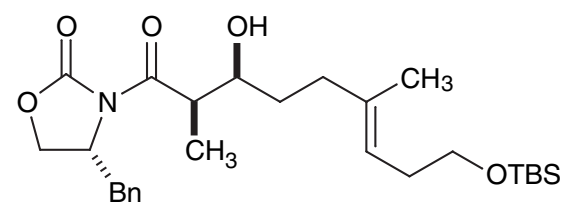

$31.7 \mathrm{mmol})$ followed by TEA $(6.0 \mathrm{~mL}, 43.0 \mathrm{mmol})$. The reaction was cooled to $-78{ }^{\circ} \mathrm{C}$ and aldehyde 8 (7.35 g, $28.6 \mathrm{mmol})$ was added in one portion. The reaction was stirred for 30 minutes, warmed to $0{ }^{\circ} \mathrm{C}$, and stirred for $2 \mathrm{~h}$. The reaction was quenched by the addition of 40 $\mathrm{mL}$ of $\mathrm{pH}=7$ phosphate buffer followed by addition of $60 \mathrm{~mL}$ of $\mathrm{MeOH}$. To the resulting slurry was then added slowly $60 \mathrm{~mL}$ of a $2: 1 \mathrm{v} / \mathrm{v}$ mixture of $\mathrm{MeOH} / 30 \%$ aq $\mathrm{H}_{2} \mathrm{O}_{2}$ and the mixture was stirred vigorously for $1 \mathrm{~h}$. The reaction was then extracted with $3 \times 100 \mathrm{~mL}^{\circ} \mathrm{Et}_{2} \mathrm{O}$ and the combined organic layers were washed with $1 \times 100 \mathrm{~mL}$ of water, $1 \times 50 \mathrm{~mL}$ of sat aq $\mathrm{NaHCO}_{3}$, $1 \times 100 \mathrm{~mL}$ of brine, and dried over $\mathrm{MgSO}_{4}$. Evaporation in vacuo yielded an oil that was purified by silica gel chromatography (gradient 4:1-2:1 hexanes/EtOAc) to give $10.52 \mathrm{~g}(88 \%)$ of $\mathbf{1 3}$ as a colorless oil. $\mathbf{R}_{\mathbf{f}}: 0.5\left(2: 1\right.$ hexanes / EtOAc) $[\alpha]_{\mathrm{D}}^{23}=-45.8^{\circ}\left(\mathrm{c}=0.60, \mathrm{CH}_{2} \mathrm{Cl}_{2}\right){ }^{\mathbf{1}} \mathbf{H}-\mathbf{N M R}(500$ $\left.\mathrm{MHz}, \mathrm{CDCl}_{3}\right) \delta 7.4-7.3(\mathrm{~m}, 3 \mathrm{H}), 7.20(\mathrm{~d}, 2 \mathrm{H}, J=7.3 \mathrm{~Hz}), 5.17(\mathrm{t}, 1 \mathrm{H}, J=7.3 \mathrm{~Hz}), 4.71(\mathrm{~m}, 1 \mathrm{H})$, $4.22(\mathrm{~m}, 2 \mathrm{H}), 3.93(\mathrm{~m}, 1 \mathrm{H}), 3.76(\mathrm{qd}, 1 \mathrm{H}, J=6.8,2.9 \mathrm{~Hz}), 3.57(\mathrm{t}, 2 \mathrm{H}, J=7.4 \mathrm{~Hz}), 3.24(\mathrm{dd}, 1 \mathrm{H}$, $J=13.7,3.3 \mathrm{~Hz}), 2.86(\mathrm{bm}, 1 \mathrm{H}), 2.76(\mathrm{dd}, 1 \mathrm{H}, J=13.7,9.3 \mathrm{~Hz}), 2.25-2.15(\mathrm{~m}, 3 \mathrm{H}), 2.05(\mathrm{~m}, 1 \mathrm{H})$, $1.63(\mathrm{~m}, 1 \mathrm{H}), 1.62(\mathrm{~s}, 3 \mathrm{H}), 1.53(\mathrm{~m}, 1 \mathrm{H}), 1.26(\mathrm{~d}, 3 \mathrm{H}, J=6.8 \mathrm{~Hz}), 0.89(\mathrm{~s}, 9 \mathrm{H}), 0.05(\mathrm{~s}, 6 \mathrm{H}){ }^{13} \mathrm{C}-$ NMR $\left(100 \mathrm{MHz}, \mathrm{CDCl}_{3}\right) \delta 177.38,152.97,136.55,134.97,129.39,128.94,127.40,120.83$, $71.14,66.11,62.99,55.06,42.15,37.73,36.04,31.96,31.79,25.93,18.34,16.10,10.53,-5.27$ FTIR (film) $v$ 3500, 2930, 1782, 1698, 1455, 1385, 1211, 1098, 836, 764, 702 HRMS (ES) Calc'd for $\mathrm{C}_{27} \mathrm{H}_{43} \mathrm{NO}_{5} \mathrm{Si}[\mathrm{M}+\mathrm{H}]$ : 490.2989; found 490.2982 


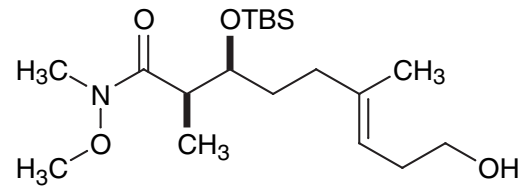

(6E) (3S,2R)-9-hydroxy- $N$-methoxy-2, 6-dimethyl- $N$-methyl3-(1,1,2,2-tetramethyl-1-silapropoxy) non-6-enamide (15). To a suspension of MeNHOMe hydrochloride (2.19 $\mathrm{g}, 22.5 \mathrm{mmol})$ in $25 \mathrm{~mL}$ of $\mathrm{THF}$ at $0{ }^{\circ} \mathrm{C}$ under $\mathrm{Ar}$ was added neat $\mathrm{Me}_{3} \mathrm{Al}(2.20$ $\mathrm{mL}, 22.9 \mathrm{mmol})$ dropwise. Gas evolution was noted. The solution was cooled to $-78{ }^{\circ} \mathrm{C}$ and a solution of $13(3.60 \mathrm{~g}, 7.35 \mathrm{mmol})$ in $15 \mathrm{~mL}$ of THF was added via cannula. The reaction was then warmed to $0{ }^{\circ} \mathrm{C}$, stirred for $1 \mathrm{~h}$, then poured onto sat aq $200 \mathrm{~mL} \mathrm{NH}_{4} \mathrm{Cl}$, acidified with 200 $\mathrm{mL} 1 \mathrm{~N} \mathrm{HCl}$ and extracted with $3 \times 100 \mathrm{~mL} \mathrm{Et}_{2} \mathrm{O}$. The combined organic layers were washed with 1 x $100 \mathrm{~mL} 1 \mathrm{~N} \mathrm{HCl}, 1 \times 50 \mathrm{~mL}$ of sat aq $\mathrm{NaHCO}_{3}, 1 \times 100 \mathrm{~mL}$ of brine then dried over $\mathrm{Na}_{2} \mathrm{SO}_{4}$. Solvent removal in vacuo gave a colorless oil that was triturated by slow addition of 20 $\mathrm{mL}$ of 10:1 hexanes/ $\mathrm{Et}_{2} \mathrm{O}$ and gentle agitation until the formation of copious white solid appeared to cease. The slurry was then filtered and the filter cake was washed with $3 \times 100 \mathrm{~mL}$ of hexanes. The combined filtrates were evaporated in vacuo to yield $2.66 \mathrm{~g}$ pure Weinreb amide $(96 \%)$ as a colorless oil. Instead of trituration smaller runs were purified by silica gel chromatography (gradient 5:2-3:2 hexanes/EtOAc). To a solution of Weinreb amide (2.66 g, $7.11 \mathrm{mmol})$, and imidazole $(2.91 \mathrm{~g}, 42.7 \mathrm{mmol})$ in $10 \mathrm{~mL}$ of DMF was added TBSCl $(2.42 \mathrm{~g}$, $16.1 \mathrm{mmol}$ ) and the reaction was stirred under Ar for $24 \mathrm{~h}$. The reaction was then poured onto $500 \mathrm{~mL}$ of water and extracted with $3 \times 100 \mathrm{~mL}$ of $\mathrm{Et}_{2} \mathrm{O}$. The combined organic extracts were washed with $1 \times 50 \mathrm{~mL}$ of $10 \%$ of aq $\mathrm{CuSO}_{4}, 3 \times 100 \mathrm{~mL}$ of water, $1 \times 100 \mathrm{~mL}$ of brine then dried over $\mathrm{Na}_{2} \mathrm{SO}_{4}$. Evaporation in vacuo gave $3.33 \mathrm{~g}(96 \%)$ of the silylated product as a colorless oil. To a solution of the bis(silylated) product $(1.50 \mathrm{~g}, 3.07 \mathrm{mmol})$ in $30 \mathrm{~mL}$ of $\mathrm{MeOH}$ at $0{ }^{\circ} \mathrm{C}$ under argon was added tetrabutylammonium hydrogensulfate $(0.117 \mathrm{~g}, 0.345 \mathrm{mmol})$ followed by $p$ toluenesulfonic acid $(0.025 \mathrm{~g}, 0.13 \mathrm{mmol})$. The reaction was stirred for $1 \mathrm{~h}$ then $10 \mathrm{~mL}$ of sat aq $\mathrm{NaHCO}_{3}$ was added and the mixture was poured onto $100 \mathrm{~mL}$ of water. The aqueous mixture was extracted with $3 \times 50 \mathrm{~mL}$ of $\mathrm{Et}_{2} \mathrm{O}$ and the combined organic layers were washed with 1x50 $\mathrm{mL}$ of water, $1 \times 50 \mathrm{~mL}$ of brine and dried over $\mathrm{MgSO}_{4}$. Evaporation in vacuo gave a colorless oil that was purified by silica gel chromatography (gradient 1:1-0:1 hexanes / $\mathrm{Et}_{2} \mathrm{O}$ ) to give $1.025 \mathrm{~g}(89 \%)$ of alcohol $\mathbf{1 5}$ as a colorless oil. $\mathbf{R}_{\mathbf{f}}: 0.33(1: 1$ hexanes $/$ EtOAc $)[\alpha]_{D}^{23}=+2.5^{\circ}$ $\left(\mathrm{c}=1.34, \mathrm{CH}_{2} \mathrm{Cl}_{2}\right){ }^{1} \mathbf{H}-\mathbf{N M R}\left(500 \mathrm{MHz}, \mathrm{CDCl}_{3}\right) \delta 5.12(\mathrm{t}, 1 \mathrm{H}, J=7.4 \mathrm{~Hz}), 3.93(\mathrm{ddd}, 1 \mathrm{H}, J=7.8$, 4.9, 4.9), $3.69(\mathrm{~s}, 3 \mathrm{H}), 3.61(\mathrm{~m}, 2 \mathrm{H}), 3.17(\mathrm{~s}, 3 \mathrm{H}), 3.00(\mathrm{bm}, 1 \mathrm{H}), 2.26(\mathrm{q}, 2 \mathrm{H}, J=6.7 \mathrm{~Hz}), 2.06(\mathrm{t}$, $2 \mathrm{H}, J=8.3 \mathrm{~Hz}), 1.61(\mathrm{~s}, 3 \mathrm{H}), 1.6-1.5(\mathrm{~m}, 2 \mathrm{H}), 1.15(\mathrm{~d}, 3 \mathrm{H}, J=6.8 \mathrm{~Hz}), 0.91(\mathrm{~s}, 9 \mathrm{H}), 0.07(\mathrm{~s}, 6 \mathrm{H})$ ${ }^{13}$ C-NMR $\left(100 \mathrm{MHz}, \mathrm{CDCl}_{3}\right) \delta 138.99,119.67,73.31,62.44,61.47,40.53,34.37,34.32,31.51$, 25.94, 18.14, 16.30, 14.86, -4.10, -4.39 FTIR (film) v 3448, 2933, 2857, 1661, 1462, 1382, 1255, 1046, 995, 835, 774, 668 HRMS (ES) Calc'd for $\mathrm{C}_{19} \mathrm{H}_{39} \mathrm{NO}_{4} \mathrm{Si}[\mathrm{M}+\mathrm{H}]:$ 374.2726; found 374.2719

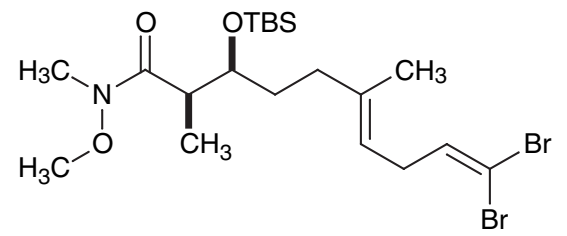

$(3 S, 2 R)(9 Z, 6 E)-10,10-d i b r o m o-N$-methoxy-2, 6-dimethyl$N$-methyl-3-(1,1,2,2-tetramethyl-1-silapro-poxy) deca-6,9dienamide (17) To a solution of alcohol 15 (1.49 g, 3.98 mmol) in $30 \mathrm{~mL}$ of $\mathrm{CH}_{2} \mathrm{Cl}_{2}$ at $0{ }^{\circ} \mathrm{C}$ under argon was added $\mathrm{NaHCO}_{3}(0.503 \mathrm{~g})$ followed by Dess-Martin periodinane $(2.32 \mathrm{~g}, 5.47 \mathrm{mmol})$. The reaction was stirred vigorously for $3 \mathrm{~h}$ then poured onto water and extracted with $3 \times 50 \mathrm{~mL}$ of $\mathrm{Et}_{2} \mathrm{O}$. The combined organic layers were washed with $2 \times 50 \mathrm{~mL}$ of sat aq $\mathrm{NaHCO}_{3}$ then dried over $\mathrm{Na}_{2} \mathrm{SO}_{4}$. Evaporation in vacuo yielded $1.39 \mathrm{~g}$ of the unstable aldehyde product as a colorless resin. To a solution of $\mathrm{CBr}_{4}(2.94 \mathrm{~g}, 8.86 \mathrm{mmol})$ in $20 \mathrm{~mL}$ of $\mathrm{CH}_{2} \mathrm{Cl}_{2}$ at $0{ }^{\circ} \mathrm{C}$ under argon was added $\mathrm{PPh}_{3}(4.65 \mathrm{~g}, 17.7 \mathrm{mmol})$ portionwise over $10 \mathrm{~min}$. The resulting orange/red solution was stirred for $30 \mathrm{~min}$, cooled to $-78{ }^{\circ} \mathrm{C}$, and the aldehyde $(1.15 \mathrm{~g}$, $3.09 \mathrm{mmol}$ ) was added via cannula as a solution in $7 \mathrm{~mL}$ of $\mathrm{CH}_{2} \mathrm{Cl}_{2}$. The reaction was warmed to 
$0{ }^{\circ} \mathrm{C}$ and stirred for $30 \mathrm{~min}$, then it was poured directly onto a silica gel column. Chromatography (gradient 6:1-4:1 hexanes / EtOAc) gave $1.20 \mathrm{~g}(74 \%)$ of the desired dibromide

17. $\mathbf{R}_{\mathbf{f}}: 0.74(1: 1$ hexanes $/ \mathrm{EtOAc})[\alpha]_{\mathrm{D}}^{23}=+5.3^{\circ}\left(\mathrm{c}=1.4, \mathrm{CH}_{2} \mathrm{Cl}_{2}\right){ }^{1} \mathbf{H}-\mathbf{N M R}\left(500 \mathrm{MHz}, \mathrm{CDCl}_{3}\right)$ $\delta 6.33(\mathrm{t}, 1 \mathrm{H}, J=6.8 \mathrm{~Hz}), 5.09(\mathrm{t}, 1 \mathrm{H}, J=7.3 \mathrm{~Hz}), 3.93(\mathrm{dt}, 1 \mathrm{H}, J=7.8,4.8 \mathrm{~Hz}), 3.69(\mathrm{~s}, 3 \mathrm{H}), 3.18$ $(\mathrm{s}, 3 \mathrm{H}), 3.00(\mathrm{bm}, 1 \mathrm{H}), 2.76(\mathrm{t}, 2 \mathrm{H}, J=7.3 \mathrm{~Hz}), 2.04(\mathrm{t}, 2 \mathrm{H}, J=8.3 \mathrm{~Hz}), 1.60(\mathrm{~s}, 3 \mathrm{H}), 1.6-1.5(\mathrm{~m}$, 2H), $1.15(\mathrm{~d}, 3 \mathrm{H}, J=6.9 \mathrm{~Hz}), 0.91(\mathrm{~s}, 9 \mathrm{H}), 0.07(\mathrm{~s}, 6 \mathrm{H}){ }^{13} \mathbf{C}-\mathbf{N M R}\left(100 \mathrm{MHz}, \mathrm{CDCl}_{3}\right) \delta 138.37$, 137.36, 118.30, 88.52, 73.37, 61.48, 40.43, 34.15, 34.06, 32.09, 25.94, 18.14, 16.33, 14.85, 4.12, -4.43 FTIR (film) 2932, 2856, 1660, 1461, 1383, 1253, 1174, 1105, 1059, 997, 835, 774 HRMS (ES) Calc'd for $\mathrm{C}_{20} \mathrm{H}_{37} \mathrm{Br}_{2} \mathrm{NO}_{3} \mathrm{Si}[\mathrm{M}+\mathrm{H}]$ : 526.0987; found 526.0988

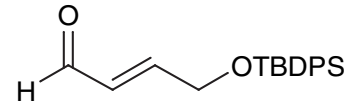

(2E)-4-(2,2-dimethyl-1,1-diphenyl-1-silaprop-oxy)but-2-enal (11). To a solution of cis-2-butene-1,4-diol (9) $(9.48 \mathrm{~g}, 107 \mathrm{mmol})$ in $300 \mathrm{~mL}$ of THF at $0{ }^{\circ} \mathrm{C}$ under argon was added $n$-BuLi $(41.0 \mathrm{~mL}, 2.60 \mathrm{M}, 107 \mathrm{mmol})$ dropwise. The resulting thick milky suspension was stirred vigorously while TBDPSCl (26.2 $\mathrm{mL}, 101 \mathrm{mmol}$ ) was added dropwise. After $1.5 \mathrm{~h}$, the reaction was quenched with $\mathrm{pH}-7 \mathrm{buffer}$ and extracted with $3 \times 300 \mathrm{~mL}$ of $\mathrm{Et}_{2} \mathrm{O}$. The combined organic layers were washed with $1 \times 200$ $\mathrm{mL}$ of brine then dried over $\mathrm{Na}_{2} \mathrm{SO}_{4}$. Evaporation in vacuo yielded $33.1 \mathrm{~g}$ (94\%) of 1-tertbutyldiphenylsilyloxy-cis-2-butene-4-ol (10) as a colorless oil that was used without purification.

To a solution of 1-tert-butyldiphenylsilyloxy-cis-2-butene-4-ol (10) (10.2 g, $31.2 \mathrm{mmol}, \mathrm{Et}_{3} \mathrm{~N}$ (18.0 mL, $129 \mathrm{mmol})$, and DMSO $(20 \mathrm{~mL})$ in $200 \mathrm{~mL}$ of $\mathrm{CH}_{2} \mathrm{Cl}_{2}$ at $0{ }^{\circ} \mathrm{C}$ was added $\mathrm{SO}_{3}$-pyridine complex $(9.75 \mathrm{~g}, 61.3 \mathrm{mmol})$. The reaction was warmed to $\mathrm{rt}$, stirred for $2 \mathrm{~h}$ then poured onto $200 \mathrm{~mL}$ of water and extracted with $3 \times 200 \mathrm{~mL}$ of $\mathrm{Et}_{2} \mathrm{O}$. The combined organic layers were washed with 1 x $100 \mathrm{~mL}$ of sat aq $\mathrm{NH}_{4} \mathrm{Cl}, 1 \times 50 \mathrm{~mL}$ of $10 \%$ aq $\mathrm{CuSO}_{4}, 3 \times 100 \mathrm{~mL}$ of water, $1 \times 100 \mathrm{~mL}$ of brine then dried over $\mathrm{Na}_{2} \mathrm{SO}_{4}$. Concentration in vacuo gave an orange oil. ${ }^{1} \mathrm{H}-$ NMR analysis of the unpurified mixture showed a 2:1 mixture of the isomeric cis and trans aldehydes. The orange oil was allowed to stand at RT under HIVAC $(<1$ torr) for $24 \mathrm{~h}$ whereupon complete isomerization to the trans aldehyde was observed by TLC. The oil was then subjected to silica gel chromatography (20:1 hexanes / EtOAc) to give $6.35 \mathrm{~g}(63 \%)$ of aldehyde 18 as a colorless solid. $\mathbf{R}_{\mathbf{f}}: 0.35$ (4:1 hexanes/ EtOAc) ${ }^{\mathbf{1}} \mathbf{H}-\mathbf{N M R}\left(500 \mathrm{MHz}, \mathrm{CDCl}_{3}\right) \delta$ $9.61(\mathrm{~d}, 1 \mathrm{H}, J=8.3 \mathrm{~Hz}), 7.66(\mathrm{~d}, 2 \mathrm{H}, J=5.8 \mathrm{~Hz}), 7.4(\mathrm{~m}, 3 \mathrm{H}), 6.84(\mathrm{dt}, 1 \mathrm{H}, J=15.1,1.0 \mathrm{~Hz}), 6.57$ $(\mathrm{dd}, 1 \mathrm{H}, J=15.1,8.3 \mathrm{~Hz}), 4.45(\mathrm{~d}, 2 \mathrm{H}, J=1.0 \mathrm{~Hz}), 1.08(\mathrm{~s}, 9 \mathrm{H}){ }^{13} \mathbf{C}-\mathbf{N M R}\left(100 \mathrm{MHz}, \mathrm{CDCl}_{3}\right) \delta$ 193.38, 155.94, 135.37, 132.66, 130.52, 129.94, 127.83, 62.91, 26.67, 19.18 FTIR (film) $v 3071$, 2931, 2857, 1688, 1472, 1427, 1362, 1113, 965, 823, 741, 702 HRMS (FAB) Calc'd for $\mathrm{C}_{20} \mathrm{H}_{24} \mathrm{O}_{2} \mathrm{Si}[\mathrm{M}+\mathrm{Na}]: 342.1890$; found 342.1890

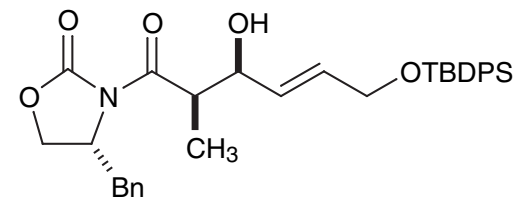

(4E)-1-[(4R)-2-oxo-4-benzyl (1,3-oxazolidin-3-yl)] (3S, 2R)-6(2,2-dimethyl-1,1-diphenyl-1-silapropoxy)-3-hydroxy-2methylhex-4-en-1-one (18). To a solution of $(R)$-4-benzyl-Npropionyl-2-oxazolidinone $(\mathbf{1 2})(3.81 \mathrm{~g}, 16.3 \mathrm{mmol})$ in $70 \mathrm{~mL}$ of $\mathrm{CH}_{2} \mathrm{Cl}_{2}$ at $0{ }^{\circ} \mathrm{C}$ under $\mathrm{Ar}$ was added $\mathrm{Bu}_{2} \mathrm{BOTf}(5.00 \mathrm{~mL}, 19.8$ mmol) followed by TEA $(3.50 \mathrm{~mL}, 25.1 \mathrm{mmol})$. The reaction was cooled to $-78{ }^{\circ} \mathrm{C}$ and trans-4tert-butyldiphenylsilyloxy-2-butenal (11) $(6.00 \mathrm{~g}, 18.5 \mathrm{mmol})$ was added in one portion. The reaction was stirred for 30 min then warmed to $0{ }^{\circ} \mathrm{C}$ and stirred for $2 \mathrm{~h}$. The reaction was quenched by the addition of $40 \mathrm{~mL}$ of $\mathrm{pH}-7$ phosphate buffer followed by addition of $60 \mathrm{~mL}$ of $\mathrm{MeOH}$. To the resulting slurry was then added slowly $60 \mathrm{~mL}$ of a 2:1 v/v mixture of $\mathrm{MeOH} /$ $30 \%$ aq $\mathrm{H}_{2} \mathrm{O}_{2}$ and the mixture was stirred vigorously for $1 \mathrm{~h}$. The reaction was then extracted with $3 \times 100 \mathrm{~mL}$ of $\mathrm{Et}_{2} \mathrm{O}$ and the combined organic layers were washed with 1x100 mL of water, 
1x sat aq $\mathrm{NaHCO}_{3}, 1 \times 100 \mathrm{~mL}$ of brine, and dried over $\mathrm{MgSO}_{4}$. Evaporation in vacuo yielded an oil that was purified by silica gel chromatography (gradient 4:1 - 2:1 hexanes/EtOAc) to give

$8.14 \mathrm{~g}(89 \%)$ of $\mathbf{1 8}$ as a colorless oil. $\mathbf{R}_{\mathrm{f}}: 0.62(1: 1$ hexanes $/$ EtOAc $) . \quad[\alpha]_{D}^{23}=-45.9^{\circ}(\mathrm{c}=1.0$, $\left.\mathrm{CH}_{2} \mathrm{Cl}_{2}\right){ }^{1} \mathbf{H}-\mathbf{N M R}\left(500 \mathrm{MHz}, \mathrm{CDCl}_{3}\right) \delta 7.68(\mathrm{~d}, 2 \mathrm{H}, J=\mathrm{Hz}), 7.44-7.28(\mathrm{~m}, 6 \mathrm{H}), 7.22(\mathrm{~d}, 2 \mathrm{H}, J=$ $7 \mathrm{~Hz}), 5.87(\mathrm{~m}, 1 \mathrm{H}), 5.79(\mathrm{dd}, 1 \mathrm{H}, J=15,4.8 \mathrm{~Hz}), 4.68(\mathrm{~m}, 1 \mathrm{H}), 4.53(\mathrm{bs}, 1 \mathrm{H}), 4.23(\mathrm{bs}, 2 \mathrm{H})$, $4.17(\mathrm{~d}, 2 \mathrm{H}, J=4.8 \mathrm{~Hz}), 3.85(\mathrm{~m}, 1 \mathrm{H}), 3.24(\mathrm{~d}, 1 \mathrm{H}, J=13.5 \mathrm{~Hz}), 2.79$ (dd, 2H, $J=13.5,9.2 \mathrm{~Hz})$, $1.25(\mathrm{~d}, 3 \mathrm{H}, J=7.0 \mathrm{~Hz}), 1.06(\mathrm{~s}, 9 \mathrm{H}){ }^{13} \mathbf{C}-\mathbf{N M R}\left(100 \mathrm{MHz}, \mathrm{CDCl}_{3}\right) \delta 176.66,153.04,135.49$, $135.00,133.59$, 133.55, 131.18, 129.65, 129.41, 128.96, 128.69, 127.66, 127.42, 71.99, 66.16, 63.70, 55.15, 42.77, 37.76, 26.79, 19.21, 11.07 FTIR (film) v 3500, 2931, 1781, 1698, 1428, 1388, 1210, 1112, 822, 702 HRMS (CI) Calc'd for $\mathrm{C}_{33} \mathrm{H}_{39} \mathrm{NO}_{5} \mathrm{Si}\left[\mathrm{M}+\mathrm{NH}_{4}\right]$ : 575.2941; found 575.2932

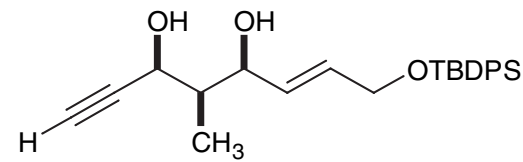

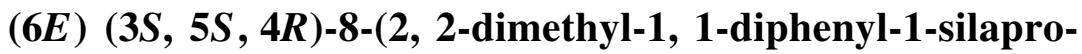
poxy)-4-methyloct-6-en-1-yne-3, 5-diol (21). To a suspension of MeNHOMe hydrochloride $(1.55 \mathrm{~g}, 15.9 \mathrm{mmol})$ in $20 \mathrm{~mL}$ of $\mathrm{THF}$ at $0{ }^{\circ} \mathrm{C}$ under argon was added neat $\mathrm{Me}_{3} \mathrm{Al}(1.50 \mathrm{~mL}, 15.6$ mmol) dropwise. Gas evolution was noted. The solution was cooled to $-78^{\circ} \mathrm{C}$ and a solution of 18 (3.01 g, $5.39 \mathrm{mmol})$ in $10 \mathrm{~mL}$ of THF was added via cannula. The reaction was then warmed to $0{ }^{\circ} \mathrm{C}$, stirred for $1 \mathrm{~h}$, then poured onto $200 \mathrm{~mL}$ of sat aq $\mathrm{NH}_{4} \mathrm{Cl}$, acidified with $200 \mathrm{~mL}$ of $1 \mathrm{~N}$ $\mathrm{HCl}$ and extracted with $3 \times 100 \mathrm{~mL}$ of $\mathrm{Et}_{2} \mathrm{O}$. The combined organic layers were washed with $1 \mathrm{x}$ $100 \mathrm{~mL}$ of $1 \mathrm{~N} \mathrm{HCl}, 1 \times 50 \mathrm{~mL}$ of sat aq $\mathrm{NaHCO}_{3}, 1 \times 100 \mathrm{~mL}$ of brine then dried over $\mathrm{MgSO}_{4}$. Solvent removal in vacuo gave a colorless oil that was triturated by slow addition of $20 \mathrm{~mL}$ of 10:1 hexanes/ $\mathrm{Et}_{2} \mathrm{O}$ and gentle agitation until the formation of copious white solid appeared to cease. The slurry was then filtered and the filter cake was washed with 3x100 mL of hexanes. The combined filtrates were evaporated in vacuo to yield $2.28 \mathrm{~g}$ of pure Weinreb amide (97\%) as a colorless oil. Instead of trituration smaller runs were purified by silica gel chromatography (gradient 5:2 - 3:2 hexanes/EtOAc). To a solution of Weinreb amide (1.42 g, $3.21 \mathrm{mmol})$ in 5 $\mathrm{mL}$ of $\mathrm{THF}$ at $0{ }^{\circ} \mathrm{C}$ under argon was added ethynylmagnesium bromide $(25 \mathrm{~mL}, 0.5 \mathrm{M}, 12.5$ $\mathrm{mmol}$ ). The reaction was stirred $3 \mathrm{~h}$ then poured onto $50 \mathrm{~mL}$ of sat aq $\mathrm{NH}_{4} \mathrm{Cl}$ and extracted with $3 \times 50 \mathrm{~mL}$ of $\mathrm{Et}_{2} \mathrm{O}$. The combined organic layers were washed with $1 \times 50 \mathrm{~mL}$ of brine and dried over $\mathrm{Na}_{2} \mathrm{SO}_{4}$. Evaporation in vacuo yielded a yellow oil that was purified by silica gel chromatography (4:1 hexanes / EtOAc) to give $1.00 \mathrm{~g}(77 \%)$ of the desired ynone as a slightly yellow oil. To a solution of ynone $(0.893 \mathrm{~g}, 2.20 \mathrm{mmol})$ in $15 \mathrm{~mL}$ of $\mathrm{THF}$ at $-78{ }^{\circ} \mathrm{C}$ under argon was added DIBAL (4.40 mL, $1 \mathrm{M}$ in $\mathrm{CH}_{2} \mathrm{Cl}_{2}, 4.40 \mathrm{mmol}$ ) dropwise. After $30 \mathrm{~min}$ the reaction was quenched by the addition of $0.1 \mathrm{~mL}$ of EtOAc and $15 \mathrm{~mL}$ of sat aq $\mathrm{Na} / \mathrm{K}$ tartrate and the slurry was warmed to rt with vigorous stirring for $12 \mathrm{~h}$. The resulting clear biphase was extracted with $3 \times 30 \mathrm{~mL}$ of $\mathrm{Et}_{2} \mathrm{O}$ and the combined organic layers were washed with $1 \times 30 \mathrm{~mL}$ of brine then dried over $\mathrm{Na}_{2} \mathrm{SO}_{4}$. Evaporation in vacuo gave a pale yellow oil that was purified by silica gel chromatography $\left(2: 1\right.$ hexanes / EtOAc) to give $0.880 \mathrm{~g}(98 \%)$ of diol 21. $\mathbf{R}_{\mathbf{f}}: 0.4(2: 1$ hexanes / EtOAc $)[\alpha]_{\mathrm{D}}^{23}=-5.2^{\circ}\left(\mathrm{c}=1.5, \mathrm{CH}_{2} \mathrm{Cl}_{2}\right) \quad{ }^{1} \mathbf{H}-\mathbf{N M R}\left(500 \mathrm{MHz}, \mathrm{CDCl}_{3}\right) \delta 7.69(\mathrm{~d}, 2 \mathrm{H}$, $J=7.0 \mathrm{~Hz}), 7.5-7.35(\mathrm{~m}, 3 \mathrm{H}), 5.89-5.79(\mathrm{~m}, 2 \mathrm{H}), 4.62(\mathrm{~s}, 1 \mathrm{H}), 4.49(\mathrm{~s}, 1 \mathrm{H}), 4.25$ (m, 2H), 2.60 (bs, 1H), $2.53(\mathrm{~s}, 1 \mathrm{H}), 2.15(\mathrm{bs}, 1 \mathrm{H}), 1.88(\mathrm{~m}, 1 \mathrm{H}), 1.10(\mathrm{~d}, 3 \mathrm{H}, J=6.5 \mathrm{~Hz}), 1.08(\mathrm{~s}, 9 \mathrm{H}){ }^{13} \mathrm{C}-$ NMR $\left(100 \mathrm{MHz}, \mathrm{CDCl}_{3}\right) \delta 135.49,133.56,130.48,130.44,129.68,127.66,83.70,74.67,73.79$, 65.98, 63.66, 60.41, 43.68, 26.78, 21.04, 19.20, 14.16, 7.46 FTIR (film) v 3288, 2933, 2856, 1466, 1427, 1379, 1256, 1112, 968, 823, 742, 702 HRMS (FAB) Calc'd for $\mathrm{C}_{25} \mathrm{H}_{32} \mathrm{O}_{3} \mathrm{Si}$ [M+Na]: 431.2019; found 431.2010 


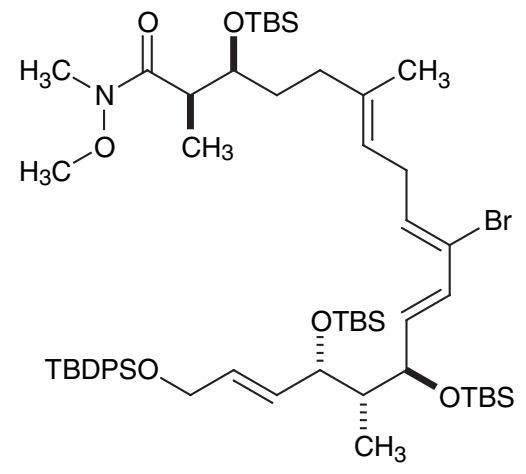

$(3 S, 15 S, 2 R, 13 R, 14 R)(9 Z, 6 E, 11 E, 16 E)$-18-(2,2-dimethyl1, 1-diphenyl-1-silapropoxy)-10-bromo-N-methoxy-2, 6, 14trimethyl-N-methyl-3, 13, 15-tris (1,1,2,2-tetramethyl-1silapropoxy)octadeca-6,9,11,16-tetraenamide $(\mathbf{2} 6)$. To a solution of diol $21(0.810 \mathrm{~g}, 1.98 \mathrm{mmol})$ and imidazole $(0.572 \mathrm{~g}$, $8.40 \mathrm{mmol}$ ) in $6 \mathrm{~mL}$ of DMF at rt under argon was added TBSCl $(0.719 \mathrm{~g}, 4.77 \mathrm{mmol})$. The reaction was stirred $36 \mathrm{~h}$ then poured onto $50 \mathrm{~mL}$ of water and extracted with $3 \times 50 \mathrm{~mL}$ of pentane. The combined organic layers were dried over $\mathrm{Na}_{2} \mathrm{SO}_{4}$ then concentrated in vacuo to afford a colorless oil. Chromatography on silica gel (20:1 hexanes / EtOAc) gave $1.19 \mathrm{~g}$ (94\%) of the desired bis(silylated) product 22. To a solution of $22(0.914 \mathrm{~g}, 1.43 \mathrm{mmol})$ in $3 \mathrm{~mL}$ of THF at rt under argon was added freshly distilled catecholborane $(0.20 \mathrm{~mL}, 1.9 \mathrm{mmol})$ followed by freshly prepared dicyclohexylborane $(0.70 \mathrm{~mL}, 0.20 \mathrm{M}$ in THF, $0.14 \mathrm{mmol})$. After $2 \mathrm{~h}$ the reaction was poured into $100 \mathrm{~mL}$ of $\mathrm{Et}_{2} \mathrm{O}$ and washed with $10 \times 20 \mathrm{~mL}$ of $1 \mathrm{~N} \mathrm{NaOH}$ (until aqueous layers were no longer colored), 1x50 $\mathrm{mL}$ of brine then dried over $\mathrm{MgSO}_{4}$. The yellow solution gradually decolorized as the remaining colored contaminants in the organic phase were adsorbed onto the $\mathrm{MgSO}_{4}$ surface. The solution was filtered and solvent removal in vacuo gave $0.952 \mathrm{~g}$ ( $97 \%$ unpurified) of the desired boronic acid $\mathbf{2 3}$ as a colorless resin that was used immediately.

To a degassed ( $4 \mathrm{x}$ freeze/pump/thaw under $\mathrm{N}_{2}$ ) solution of dibromide $17(1.00 \mathrm{~g}, 1.89 \mathrm{mmol})$ and boronic acid $23(1.67 \mathrm{~g}, 2.44 \mathrm{mmol})$ in $30 \mathrm{~mL}$ of THF and $10 \mathrm{~mL}$ of water was added $\mathrm{Pd}\left(\mathrm{PPh}_{3}\right)_{4}$ $(0.187 \mathrm{~g}, 0.162 \mathrm{mmol})$ followed by $\mathrm{Tl}_{2} \mathrm{CO}_{3}(1.73 \mathrm{~g}, 3.70 \mathrm{mmol})$. A yellow precipitate rapidly formed. After $5 \mathrm{~h}$ the reaction was poured onto $100 \mathrm{~mL}$ of $\mathrm{Et}_{2} \mathrm{O}$ and washed with $1 \times 100 \mathrm{~mL}$ of 1 $\mathrm{M} \mathrm{NaHSO}_{4}$ (gas evolution!). The resulting precipitate was removed by filtration through Celite and the aqueous layer was discarded. The remaining organic layer was then washed with $2 \times 50$ $\mathrm{mL}$ of water, $1 \times 50 \mathrm{~mL}$ of brine then dried over $\mathrm{Na}_{2} \mathrm{SO}_{4}$. Evaporation in vacuo gave an orange oil. Chromatography on silica gel (gradient 10:1-6:1 hexanes / EtOAc) gave $1.73 \mathrm{~g}(84 \%)$ of the desired coupled product $\mathbf{2 6}$ as a slightly yellow oil. $\mathbf{R}_{\mathbf{f}}$ : 0.34 (9:1 hexanes / EtOAc) $[\alpha]_{0}^{28}=+0.66^{\circ}\left(\mathrm{c}=0.90, \mathrm{CH}_{2} \mathrm{Cl}_{2}\right){ }^{1} \mathrm{H}-\mathrm{NMR}\left(500 \mathrm{MHz}, \mathrm{CDCl}_{3}\right) \delta 7.67(\mathrm{~d}, 2 \mathrm{H}, J=7.8 \mathrm{~Hz}), 7.42-$ $7.35(\mathrm{~m}, 3 \mathrm{H}), 6.15-6.00(\mathrm{~m}, 2 \mathrm{H}), 5.80(\mathrm{t}, 1 \mathrm{H}, J=6.7 \mathrm{~Hz}), 5.75(\mathrm{dd}, 1 \mathrm{H}, J=15.7,7.4 \mathrm{~Hz}), 5.68(\mathrm{dt}$, $1 \mathrm{H}, J=15.7,4.8 \mathrm{~Hz}), 5.15(\mathrm{t}, 1 \mathrm{H}, 6.8 \mathrm{~Hz}), 4.22(\mathrm{t}, 1 \mathrm{H}, J=5.4 \mathrm{~Hz}), 4.18(\mathrm{~d}, 2 \mathrm{H}, J=4.4 \mathrm{~Hz}), 4.12(\mathrm{t}$, $1 \mathrm{H}, J=6.3$ ), $3.93(\mathrm{dt}, 1 \mathrm{H}, J=8.8,4.4 \mathrm{~Hz}), 3.68(\mathrm{~s}, 3 \mathrm{H}), 3.17$ (s, 3H), $2.97(\mathrm{bm}, 1 \mathrm{H}+\mathrm{t}, 2 \mathrm{H}, J=6.8$ $\mathrm{Hz}), 2.05(\mathrm{t}, 2 \mathrm{H}, J=7.3 \mathrm{~Hz}), 1.60-1.45(\mathrm{~m}, 2 \mathrm{H}+\mathrm{s}, 3 \mathrm{H}), 1.16(\mathrm{~d}, 3 \mathrm{H}, J=6.9 \mathrm{~Hz}), 1.05(\mathrm{~s}, 9 \mathrm{H}), 0.95$ (d, 3H, J=6.9 Hz), 0.90 (s, 9H), 0.89 (s, 18H), 0.066 (s, 6H), 0.034 (s, 3H), 0.010 (s, 6H), -0.016 (s, 3H) ${ }^{13}$ C-NMR $\left(100 \mathrm{MHz}, \mathrm{CDCl}_{3}\right) \delta 137.43,136.61,135.48,133.69,132.74,132.19,129.74$, 129.60, 129.07, 127.64, 124.50, 119.88, 73.85, 73.37, 73.34, 63.87, 61.44, 47.51, 40.40, 34.21, $34.10,31.57,30.77,26.77,25.93,25.63,22.64,19.21,18.21,18.19,18.13,16.33,14.78,14.13$, $9.72,-3.65,-3.73,-4.13,-4.45,-4.75$ FTIR (film) v 2930, 2857, 1712, 1633, 1471, 1254, 1112, $836,776,702$

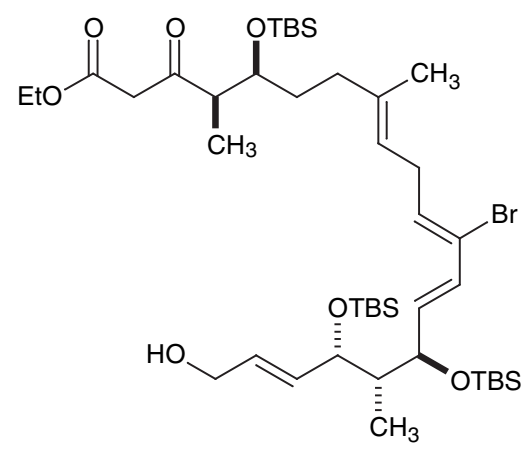

Ethyl $(5 S, 17 S, 4 R, 15 R, 16 R)(11 Z, 8 E, 13 E, 18 E)-12$-bromo-20hydroxy-4, 8, 16-trimethyl-3-oxo-5, 15, 17-tris $(1,1,2$, 2tetramethyl-1-silapropoxy) icosa-8,11,13,18-tetraenoate (29). To a solution of amide $26(1.14 \mathrm{~g}, 1.05 \mathrm{mmol})$ in $10 \mathrm{~mL}$ of THF at $-78{ }^{\circ} \mathrm{C}$ under argon was added DIBAL $(0.22 \mathrm{~mL}, 1.23 \mathrm{mmol})$ dropwise. The reaction was stirred for $3 \mathrm{~h}$ then quenched by the addition of $0.5 \mathrm{~mL}$ of EtOAc followed by $10 \mathrm{~mL}$ of sat aq $\mathrm{Na} / \mathrm{K}$ 
tartrate. The resulting slurry was warmed to rt, stirred vigorously for $12 \mathrm{~h}$, then extracted with $3 \times 50 \mathrm{~mL}$ of $\mathrm{Et}_{2} \mathrm{O}$. The combined organic layers were washed with $1 \times 50 \mathrm{~mL}$ of brine and dried over $\mathrm{Na}_{2} \mathrm{SO}_{4}$. Evaporation in vacuo yielded a colorless oil that was immediately redissolved in 8 $\mathrm{mL}$ of $\mathrm{CH}_{2} \mathrm{Cl}_{2}$ at $\mathrm{rt}$ under argon. In a separate flask, $\mathrm{SnCl}_{2}(0.230 \mathrm{~g}, 0.880 \mathrm{mmol})$ was suspended in $2 \mathrm{~mL}$ of $\mathrm{CH}_{2} \mathrm{Cl}_{2}$ at $\mathrm{rt}$ and EDA (1.25 g, $8.00 \mathrm{mmol}$ ) was added (gas evolution!). To this opaque yellow mixture was then added the aldehyde solution and the reaction was stirred vigorously for $2 \mathrm{~h}$. The reaction was then poured onto $50 \mathrm{~mL}$ of brine and extracted with $3 \times 50$ $\mathrm{mL}$ of $\mathrm{Et}_{2} \mathrm{O}$. The combined organic layers were dried over $\mathrm{Na}_{2} \mathrm{SO}_{4}$ and solvent removal in vacuo gave a yellow oil. The oil was placed under HIVAC ( $<1$ torr) for $24 \mathrm{~h}$ to remove the bulk of residual EDA then chromatographed on silica gel (gradient 50:1-20:1 hexanes / EtOAc) to afford $0.818 \mathrm{~g}(70 \%)$ of $\beta$-keto ester $\mathbf{2 8}$ as a colorless oil.

To a stirring solution of TBAF trihydrate $(0.0569 \mathrm{~g}, 0.181 \mathrm{mmol})$ and AcOH $(0.0109 \mathrm{~g}, 0.182$ $\mathrm{mmol})$ in $1 \mathrm{~mL}$ of DMF in a plastic vial was added the $\beta$-keto-ester $28(0.145 \mathrm{~g}, 0.130 \mathrm{mmol})$ as a solution in $1 \mathrm{~mL}$ of DMF. After $3 \mathrm{~h}$ the reaction was poured onto $20 \mathrm{~mL}$ of water and extracted with $3 \times 20 \mathrm{~mL}$ of $\mathrm{Et}_{2} \mathrm{O}$. The combined organic layers were washed with $1 \times 30 \mathrm{~mL}$ of water, 1 x $30 \mathrm{~mL}$ of sat aq $\mathrm{NaHCO}_{3}, 1 \times 30 \mathrm{~mL}$ of brine then dried over $\mathrm{Na}_{2} \mathrm{SO}_{4}$. Evaporation in vacuo yielded a yellow oil that was purified by silica gel chromatography (6:1 hexanes / EtOAc) to give $0.105 \mathrm{~g}(92 \%)$ of the desired alcohol 29 as a colorless oil. $\mathbf{R}_{\mathbf{f}}: 0.39$ (4:1 hexanes / EtOAc) $[\alpha]_{\mathrm{D}}^{23}=-15.8^{\circ}\left(\mathrm{c}=1.1, \mathrm{CH}_{2} \mathrm{Cl}_{2}\right){ }^{1} \mathbf{H}-\mathbf{N M R}\left(500 \mathrm{MHz}, \mathrm{CDCl}_{3}, 1: 1 \mathrm{keto} / \mathrm{enol}\right) \delta 12.14(\mathrm{~s}, 0.5 \mathrm{H}$, enol-OH), 6.09 (d, 1H, J=14.6 Hz), 6.03 (dd, 1H, J=14.6, $6.3 \mathrm{~Hz}), 5.83$ (t, 1H, J=6.9 Hz), 5.72 $(\mathrm{m}, 2 \mathrm{H}), 5.16(\mathrm{bm}, 1 \mathrm{H}), 5.01(\mathrm{~s}, 0.5 \mathrm{H}$, enol), $4.23(\mathrm{t}, 1 \mathrm{H}, J=5.4 \mathrm{~Hz}), 4.18$ (q, 2H, J=7.3 Hz), 4.16-4.10 (m, 3H), 3.92 (q, 0.5H, J=5.8 Hz, keto), 3.84 (dt, 0.5H, J=6.8, 4.9 Hz, enol), 3.60 (d, $0.5 \mathrm{H}, J=15.6 \mathrm{~Hz}$, keto), 3.53 (d, $0.5 \mathrm{H}, J=15.6 \mathrm{~Hz}$, keto), 3.00 (t, 2H, $J=6.8 \mathrm{~Hz}), 2.84$ (m, 0.5H, enol), $2.36(\mathrm{~m}, 0.5 \mathrm{H}$, keto), 2.1-2.0 (m, 1.5H, keto + enol), $1.91(\mathrm{~m}, 0.5 \mathrm{H}$, enol), $1.64(\mathrm{~s}, 3 \mathrm{H})$, 1.6-1.5 (m, 2.5H, keto + enol), $1.41(\mathrm{~m}, 0.5 \mathrm{H}$, enol $), 1.28(\mathrm{~m}, 3 \mathrm{H}), 1.09(\mathrm{~d}, 1.5 \mathrm{H}, \mathrm{J}=6.8 \mathrm{~Hz}$, keto), 1.06 (d, 1.5H, J=6.9 Hz, enol), 0.94 (d, 3H, J=6.8 Hz), 0.89 (s, 18H), 0.87 (s, 9H), 0.077 $(\mathrm{s}, 3 \mathrm{H}), 0.073(\mathrm{~s}, 3 \mathrm{H}), 0.030(\mathrm{~s}, 3 \mathrm{H}), 0.021(\mathrm{~s}, 3 \mathrm{H}),-0.006(\mathrm{~s}, 3 \mathrm{H}),-0.011(\mathrm{~s}, 3 \mathrm{H}){ }^{\mathbf{1 3}} \mathbf{C}-\mathbf{N M R}(100$ $\left.\mathrm{MHz} \mathrm{CDCl}_{3}\right) \delta 205.26,180.66,172.80,167.48,137.00,136.54,136.48,136.35,134.76,134.35$, $132.27,132.03,129.69,129.67,129.59,129.25,129.17,127.67,124.57,124.42,120.42,120.18$, 89.64, 73.78, 73.57, 73.25, 73.21, 72.74, 63.21, 61.16, 59.92, 51.68, 49.45, 47.36, 43.88, 35.69, $34.74,33.58,32.32,30.76,30.73,26.53,25.91,25.89,25.84,18.98,18.16,18.08,18.02,16.33$, $16.31,14.27,14.08,12.20,11.66,9.84,-3.61,-3.73,-4.28,-4.41,-4.77$ FTIR (film) $\vee 3445$, 2954, 2939, 2886, 1747, 1715, 1651, 1472, 1361, 1255, 1225, 1094, 1030, 957, 835, 774, 672 HRMS (FAB) Calc'd for $\mathrm{C}_{43} \mathrm{H}_{81} \mathrm{BrO}_{7} \mathrm{Si}_{3}[\mathrm{M}+\mathrm{Na}]$ : 895.4371; found 895.4379

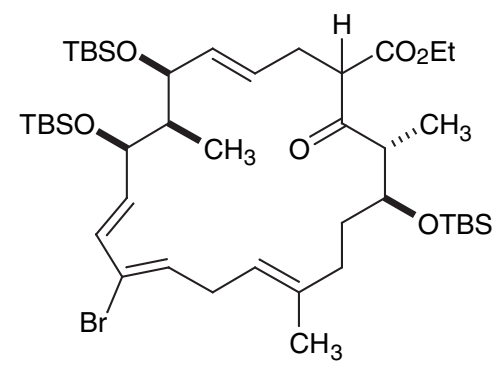

Ethyl $(5 S, 17 S, 6 R, 7 R, 18 R)$-10-bromo-6, 14, 18-trimethyl-19oxo-5, 7, 17-tris (1, 1, 2, 2-tetramethyl-1-silapropoxy) cyclononadeca-3, 8, 10, 13-tetraene carboxylate $(31)$. To a solution of alcohol $29(0.020 \mathrm{~g}, 0.0230 \mathrm{mmol})$ in $1 \mathrm{~mL}$ of $\mathrm{CH}_{2} \mathrm{Cl}_{2}$ at $0{ }^{\circ} \mathrm{C}$ under argon was added a pre-mixed solution of $\mathrm{PPh}_{3}(0.0125 \mathrm{~g}$, $0.0477 \mathrm{mmol})$, imidazole $(0.0110 \mathrm{~g}, 0.162 \mathrm{mmol})$, and iodine $(0.0159 \mathrm{~g}, 0.0626 \mathrm{mmol})$ in $1 \mathrm{~mL}$ of $\mathrm{CH}_{2} \mathrm{Cl}_{2}$. After $5 \mathrm{~min}$ the reaction was diluted to $10 \mathrm{~mL}$ of with hexane (precipitate formed) and the orange heterogeneous mixture was passed through a short plug of silica. The silica plug was washed with $3 \times 2 \mathrm{~mL}$ of 10:1 hexanes / EtOAc and the combined filtrates were concentrated in vacuo to give a quantitative yield of allylic iodide $\mathbf{3 0}$ as a colorless resin. The iodide was immediately redissolved in $5 \mathrm{~mL}$ of THF and $\mathrm{Cs}_{2} \mathrm{CO}_{3}(0.0110 \mathrm{~g}, 0.034 \mathrm{mmol})$ was added. After $5 \mathrm{~h}$ of vigorous stirring the reaction was quenched with $1 \mathrm{~mL}$ of $1 \mathrm{~N} \mathrm{HCl}$ (gas evolution!), 
diluted with $20 \mathrm{~mL}$ of EtOAc and washed with $2 \times 20 \mathrm{~mL}$ of water, $1 \times 20 \mathrm{~mL}$ of sat aq $\mathrm{NaHCO}_{3}$, $1 \times 20 \mathrm{~mL}$ of brine then dried over $\mathrm{Na}_{2} \mathrm{SO}_{4}$. Solvent removal in vacuo afforded a colorless film that was purified by silica gel chromatography (50:1 hexane / EtOAc) to give $0.0151 \mathrm{~g}(77 \%)$ of the desired macrocycle $\mathbf{3 1}$ as a 1:1 mixture of diastereomers. A portion of the more polar isomer eluted free of its epimer and was characterized. In practice, the mixture was used in the subsequent step without being separated. $\mathbf{R}_{\mathbf{f}}: 0.65(20: 1$ hexanes $/$ EtOAc $)[\alpha]_{D}^{23}=-120.5^{\circ}$ $\left(\mathrm{c}=0.66, \mathrm{CH}_{2} \mathrm{Cl}_{2}\right){ }^{1} \mathrm{H}-\mathrm{NMR}\left(500 \mathrm{MHz}, \mathrm{CDCl}_{3}\right) \delta 5.92(\mathrm{~m}, 2 \mathrm{H}), 5.80(\mathrm{t}, 1 \mathrm{H}, J=7.4 \mathrm{~Hz}), 5.53(\mathrm{dd}$, $1 \mathrm{H}, J=15.1,6.8 \mathrm{~Hz}), 5.24(\mathrm{t}, 1 \mathrm{H}, J=7.4 \mathrm{~Hz}), 5.09$ (dt, 1H, J=15.1, 7.3 Hz), 4.17 (q, 2H, $J=6.8$ $\mathrm{Hz}), 3.91(\mathrm{dd}, 1 \mathrm{H}, J=8.3,6.3 \mathrm{~Hz}), 3.85(\mathrm{~m}, 1 \mathrm{H}), 3.76(\mathrm{~m}, 1 \mathrm{H}), 3.71(\mathrm{t}, 1 \mathrm{H}, J=7.2 \mathrm{~Hz}), 2.94(\mathrm{t}$, $2 \mathrm{H}, J=7.8 \mathrm{~Hz}), 2.92(\mathrm{~m}, 1 \mathrm{H}), 2.50(\mathrm{t}, 2 \mathrm{H}, J=6.9 \mathrm{~Hz}), 2.09(\mathrm{~m}, 1 \mathrm{H}), 1.94(\mathrm{~m}, 1 \mathrm{H}), 1.67(\mathrm{~s}, 3 \mathrm{H})$, $1.64(\mathrm{~m}, 2 \mathrm{H}), 1.25(\mathrm{~m}, 3 \mathrm{H}), 1.03(\mathrm{~d}, 3 \mathrm{H}, J=7.3 \mathrm{~Hz}), 1.01(\mathrm{~d}, 3 \mathrm{H}, J=7.3 \mathrm{~Hz}), 0.89(\mathrm{~s}, 9 \mathrm{H}), 0.88$ (s, 9H), 0.87 (s, 9H), 0.04 (s, 3H), 0.016 (s, 3H), 0.014 (s, 3H), $0.003(\mathrm{~s}, 6 \mathrm{H}),-0.007$ (s, 3H) ${ }^{13} \mathrm{C}-$ NMR $\left(100 \mathrm{MHz}, \mathrm{CDCl}_{3}\right) \delta$ 205.62, 169.14, 136.45, 135.36, 132.85, 130.87, 130.12, 127.86, $123.80,120.94,75.92,75.20,72.73,70.01,61.35,58.36,50.69,47.31,36.04,33.58,29.99$, $25.91,25.87,25.84,18.23,18.20,18.05,15.92,14.13,13.57,11.95,-3.83,-4.01,-4.27,-4.72$, 5.01 FTIR (film) v 2929, 2856, 1738, 1715, 1471, 1364, 1255, 1112, 1057, 835, 774 HRMS (FAB) Calc'd for $\mathrm{C}_{43} \mathrm{H}_{79} \mathrm{BrO}_{6} \mathrm{Si}_{3}[\mathrm{M}+\mathrm{Na}]:$ 877.4266; found 877.4273

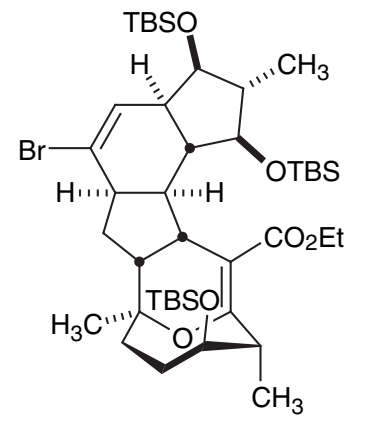

Ethyl $(1 S, 10 S, 17 S, 8 R, 9 R, 16 R)$-5-bromo-1, 9, 16-trimethyl-20-oxa8, 10, 17-tris $(1,1,2$, 2-tetramethyl-1-silapropoxy) pentacyclo[13.4.1.0<2,13>.0<4,12>.0<7,11>]icosa-5,14-diene-14-carboxylate (34). To a suspension of $\mathrm{Ph}_{2} \mathrm{Se}_{2} \mathrm{O}_{3}(0.0492 \mathrm{~g}, 0.137 \mathrm{mmol})$ and $\mathrm{SO}_{3}$-pyridine complex $(0.0229 \mathrm{~g}, 0.144 \mathrm{mmol})$ in $1 \mathrm{~mL}$ of THF at rt under argon was added $\mathrm{Et}_{3} \mathrm{~N}(0.050 \mathrm{~mL}, 0.36 \mathrm{mmol})$ and the mixture was stirred vigorously for $15 \mathrm{~min}$ to form an "oxidant solution." To a solution of macrocycle $\mathbf{3 1}$ $(0.0580 \mathrm{~g}, 0.0677 \mathrm{mmol})$ in $1 \mathrm{~mL}$ of THF at $\mathrm{rt}$ under argon was added $\mathrm{Et}_{3} \mathrm{~N}$ $(0.050 \mathrm{~mL}, 0.36 \mathrm{mmol})$ followed by the oxidant solution and the reaction was stirred for $2 \mathrm{~h}$. Hexane $(10 \mathrm{~mL})$ was then added (a precipitate formed). The resulting opaque mixture was filtered through a short plug of silica and the bright yellow filtrate was heated to $50{ }^{\circ} \mathrm{C}$ for $6 \mathrm{~h}$. Concentration in vacuo gave a yellow oil that was purified by silica gel chromatography (4:1 hexane / benzene) to give $0.036 \mathrm{~g}(63 \%)$ of the desired Diels-Alder adduct

34 as a colorless film. $\mathbf{R}_{\mathrm{f}}: 0.69(20: 1$ hexanes/ EtOAc $)[\alpha]_{D}^{23}=-44.4^{\circ}\left(\mathrm{c}=0.15, \mathrm{CH}_{2} \mathrm{Cl}_{2}\right){ }^{1} \mathbf{H}-$ NMR (500 MHz, $\left.\mathrm{CDCl}_{3}\right) \delta 5.89(\mathrm{~s}, 1 \mathrm{H}), 4.23(\mathrm{~m}, 1 \mathrm{H}), 4.02(\mathrm{~m}, 1 \mathrm{H}), 3.70(\mathrm{~m}, 1 \mathrm{H}), 3.67(\mathrm{q}, 1 \mathrm{H}$, $J=6.8 \mathrm{~Hz}), 3.63(\mathrm{~d}, 1 \mathrm{H}, J=3.4 \mathrm{~Hz}), 3.59$ (bs, 1H), $2.78(\mathrm{q}, 1 \mathrm{H}, J=5.9 \mathrm{~Hz}), 2.46(\mathrm{~m}, 1 \mathrm{H}), 2.38(\mathrm{~m}$, $1 \mathrm{H}), 2.22(\mathrm{td}, 1 \mathrm{H}, J=12.2,7.8 \mathrm{~Hz}), 2.1-2.0(\mathrm{~m}, 3 \mathrm{H}), 1.85(\mathrm{~m}, 1 \mathrm{H}), 1.73(\mathrm{~m}, 2 \mathrm{H}), 1.54(\mathrm{~s}, 3 \mathrm{H})$, $1.46(\mathrm{~m}, 1 \mathrm{H}), 1.28(\mathrm{t}, 3 \mathrm{H}, J=7.3 \mathrm{~Hz}), 1.24(\mathrm{~s}, 3 \mathrm{H}), 1.07$ (d, 3H, J=7.3 Hz), 1.01 (d, 3H, J=7.8 $\mathrm{Hz}), 0.88$ (s, 9H), $0.86(\mathrm{~s}, 9 \mathrm{H}), 0.84(\mathrm{~s}, 9 \mathrm{H}), 0.14$ (s, 3H), 0.10 (s, 3H), 0.04 (s, 6H), -0.005 (s, $6 \mathrm{H}){ }^{13} \mathrm{C}-\mathrm{NMR}\left(100 \mathrm{MHz}, \mathrm{CDCl}_{3}\right) \delta 168.21,165.79,128.40,127.72,117.95,82.55,79.47,78.60$, 73.78, 59.49, 53.06, 50.71, 48.65, 47.86, 46.21, 46.08, 42.73, 42.65, 34.06, 27.92, 27.82, 25.98, $25.88,25.80,25.69,23.99,19.01,18.11,17.93,17.69,14.55,13.17,-3.44,-4.35,-4.43,-4.86$, 4.95, -5.18 FTIR (film) v 2928, 2854, 1698, 1627, 1465, 1359, 1258, 1055, 836, 767 HRMS (FAB) Calc'd for $\mathrm{C}_{43} \mathrm{H}_{77} \mathrm{BrO}_{6} \mathrm{Si}_{3}[\mathrm{M}+\mathrm{H}]$ : 853.4289; found 853.4296. 


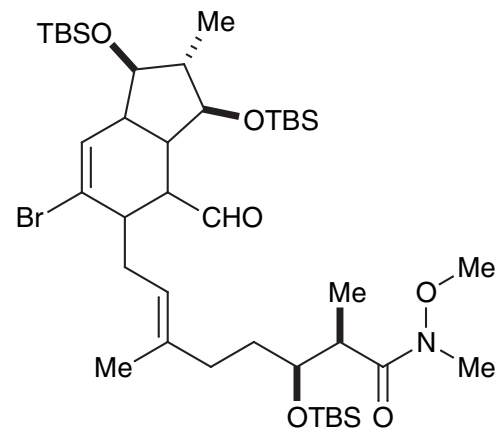

IMDA cycloadducts $(\mathbf{3 6 a}+\mathbf{3 7 a})$ A solution of $\alpha, \beta$-unsaturated aldehyde $44 \mathbf{a}(0.01 \mathrm{~g})$ in $0.75 \mathrm{~mL}$ of $\mathrm{CDCl}_{3}$ in a standard NMR tube was heated at $60^{\circ} \mathrm{C}$ until complete conversion of $\mathbf{3 5 a}$ to two new species was observed by ${ }^{1} \mathrm{H}-\mathrm{NMR}(3 \mathrm{~h})$. The ratio of the two new species was determined to be $\mathbf{3 7 6 a : 3 7 a}=37: 63$ by integration of the $\mathrm{C} 10$ methine signals in the ${ }^{1} \mathrm{H}-\mathrm{NMR}$ spectrum of the mixture. Purification by silica gel chromatography $(8: 1$ hexanes/EtOAc) gave $0.003 \mathrm{~g}(30 \%)$ of $\mathbf{3 6 a}$ and $0.005 \mathrm{~g}(50 \%)$ of 37a. 36a: ${ }^{1} \mathbf{H}-\mathbf{N M R}\left(500 \mathrm{MHz}, \mathrm{CDCl}_{3}\right) \delta 9.66(\mathrm{~d}, 1 \mathrm{H}, J=5.4 \mathrm{~Hz})$, $6.03(\mathrm{~s}, 1 \mathrm{H}), 5.02(\mathrm{t}, 1 \mathrm{H}, J=6.3 \mathrm{~Hz}), 3.93(\mathrm{~m}, 1 \mathrm{H}), 3.68(\mathrm{~s}, 3 \mathrm{H}), 3.67(\mathrm{~m}, 1 \mathrm{H}), 3.37(\mathrm{dd}, 1 \mathrm{H}$, $J=8.8,3.9 \mathrm{~Hz}), 3.18(\mathrm{~s}, 3 \mathrm{H}), 2.98(\mathrm{bm}, 1 \mathrm{H}), 2.88(\mathrm{td}, 1 \mathrm{H}, J=9.9,8.8 \mathrm{~Hz}), 2.76(\mathrm{~m}, 1 \mathrm{H}), 2.55(\mathrm{~m}$, 2H), $2.00(\mathrm{~m}, 2 \mathrm{H}), 1.82(\mathrm{~m}, 1 \mathrm{H}), 1.61(\mathrm{~s}, 3 \mathrm{H}), 1.5-1.6(\mathrm{~m}, 2 \mathrm{H}), 1.14(\mathrm{~d}, 3 \mathrm{H}, J=6.8 \mathrm{~Hz}), 1.03(\mathrm{~d}$, $3 \mathrm{H}, J=7.4 \mathrm{~Hz}), 0.90(\mathrm{~s}, 18 \mathrm{H}), 0.85(\mathrm{~s}, 9 \mathrm{H}), 0.068(\mathrm{~s}, 3 \mathrm{H}), 0.062(\mathrm{~s}, 3 \mathrm{H}), 0.058(\mathrm{~s}, 3 \mathrm{H}), 0.045$ (s, $3 \mathrm{H}), 0.036(\mathrm{~s}, 3 \mathrm{H}),-0.031(\mathrm{~s}, 3 \mathrm{H}) .37 \mathrm{a}:{ }^{1} \mathbf{H}-\mathbf{N M R}\left(500 \mathrm{MHz}, \mathrm{CDCl}_{3}\right) \delta 9.63(\mathrm{~s}, 1 \mathrm{H}), 6.22(\mathrm{~s}, 1 \mathrm{H})$, 4.97 (t, 1H, J=7.4 Hz), 4.04 (d, 1H, 3.4 Hz), 3.92 (m, 1H), 3.69 (s, 3H), 3.24 (dd, 1H, J=9.8, 4.9 $\mathrm{Hz}), 3.18$ (s, 3H), $3.02(\mathrm{~m}, 3 \mathrm{H}), 2.64(\mathrm{dd}, 1 \mathrm{H}, J=12.2,10.3 \mathrm{~Hz}), 2.4$ (bd, 1H, J=11.9 Hz), 2.13 $(\mathrm{m}, 1 \mathrm{H}), 1.98(\mathrm{t}, 2 \mathrm{H}, J=8.8 \mathrm{~Hz}), 1.7-1.8(\mathrm{~m}, 2 \mathrm{H}), 1.5(\mathrm{~s}, 3 \mathrm{H}), 1.14(\mathrm{~d}, 3 \mathrm{H}, J=6.8 \mathrm{~Hz}), 1.07$ (d, 3H, $J=7.4 \mathrm{~Hz}$ ), 0.90 (s, 9H), 0.88 (s, 9H), 0.81 (s, 9H), 0.068 (s, 3H), 0.063 (s, 6H), 0.053 (s, 3H), $0.018(\mathrm{~s}, 3 \mathrm{H}),-0.084(\mathrm{~s}, 3 \mathrm{H})$ Stereochemistry: The relative stereochemical assignments of IMDA products 36a and 37a were determined using NOESY analysis and the diagnostic NOE's are shown in Figure 1 below.
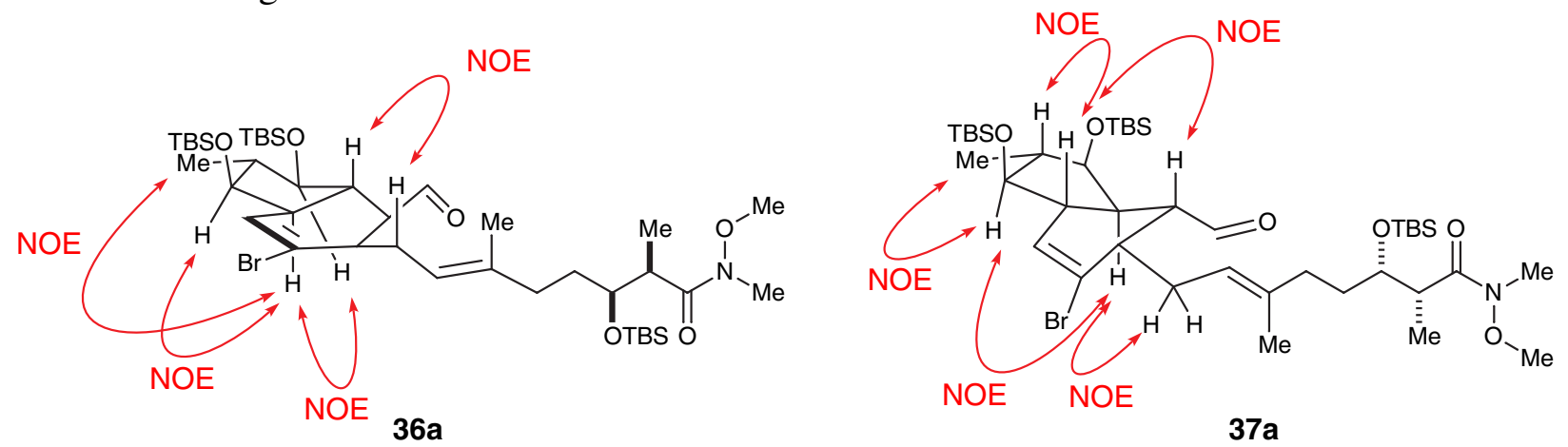

Figure 1. Diagnostic NOE cross peaks observed in NOESY analyses of 36a and 37a.

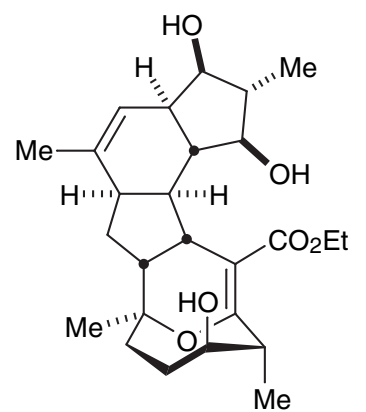

Ethyl (1 $S, 9 S, 10 S, 17 S, 8 R, 16 R)-8,10,17$-trihydroxy-1, 5, 9, 16tetramethyl-20-oxapentacyclo $[13.4 .1 .0<2,13>.0<4,12>.0<7,11>]$ icosa-5, 14-diene-14-carboxylate (39) Diels-Alder adduct 34 (0.036 g, $0.042 \mathrm{mmol}$ ) was dissolved in $\mathrm{HF}-\mathrm{CH}_{3} \mathrm{CN}$ (95:5:1 $\mathrm{CH}_{3} \mathrm{CN} / 48 \%$ aq $\mathrm{HF} /$ water, $10 \mathrm{~mL}$ ) in a plastic vial at $\mathrm{rt}$ under argon. After $4 \mathrm{~h}$ the reaction was poured onto $50 \mathrm{~mL}$ of sat aq $\mathrm{NaHCO}_{3}$ (gas evolution!) and extracted with $3 \times 20 \mathrm{~mL}$ of EtOAc. The combined organic layers were washed with $1 \times 20 \mathrm{~mL}$ of brine and dried over $\mathrm{Na}_{2} \mathrm{SO}_{4}$. Evaporation in vacuo yielded a colorless oil that was purified by silica gel chromatography (100\% EtOAc) to give the desire product as an oil. Azeotropic removal of residual EtOAc with hexane $(3 \times 10$ $\mathrm{mL})$ gave $0.0186 \mathrm{~g}(89 \%)$ of $\mathbf{3 8}$ as a colorless amorphous solid. $\mathbf{R}_{\mathbf{f}}: 0.29(100 \% \mathrm{EtOAc})[\alpha]_{D}^{23}=$ $-0.66^{\circ}\left(\mathrm{c}=0.75, \mathrm{CH}_{2} \mathrm{Cl}_{2}\right)$ To a portion of the desilylated product $38(0.010 \mathrm{~g}, 0.019 \mathrm{mmol})$ in 1.0 $\mathrm{mL}$ of DMF was added $\mathrm{Pd}(\mathrm{dppf}) \mathrm{Cl}_{2}-\mathrm{CH}_{2} \mathrm{Cl}_{2}(0.0021 \mathrm{~g}, 0.0026 \mathrm{mmol})$ followed by a premixed solution of $\mathrm{Cs}_{2} \mathrm{CO}_{3}(0.573 \mathrm{~g}, 1.75 \mathrm{mmol})$ and trimethylboroxine $(0.048 \mathrm{~g}, 0.38 \mathrm{mmol})$ in $0.75 \mathrm{~mL}$ 
of water. The reaction was heated at $80{ }^{\circ} \mathrm{C}$ under argon, stirred vigorously for $2 \mathrm{~h}$, then was then cooled to rt, poured onto $10 \mathrm{~mL}$ of water, and extracted with $3 \times 5 \mathrm{~mL}$ of $\mathrm{Et}_{2} \mathrm{O}$. The combined ethereal extracts were dried over $\mathrm{Na}_{2} \mathrm{SO}_{4}$. Evaporation in vacuo gave a yellow film that was purified by silica gel chromatography (100\% EtOAc) to give $0.0064 \mathrm{~g}(71 \%)$ of the desired methyl adduct 39. A small amount $(\sim 5 \%)$ of the saponified Suzuki product (FR182877 secoacid) could be recovered from the combined aqueous layers after acidification $(1 \mathrm{~N} \mathrm{HCl})$ and extraction with $\mathrm{CH}_{2} \mathrm{Cl}_{2} . \quad \mathbf{R}_{\mathrm{f}}: 0.34\left(100 \%\right.$ EtOAc) $[\alpha]_{\mathrm{D}}^{23}=-18.3\left(\mathrm{c}=0.13, \mathrm{CH}_{2} \mathrm{Cl}_{2}\right){ }^{\mathbf{1}} \mathbf{H}-\mathbf{N M R}(500$ $\left.\mathrm{MHz}, \mathrm{C}_{6} \mathrm{D}_{6}\right) \delta 5.31(\mathrm{~s}, 1 \mathrm{H}), 4.48(\mathrm{bd}, 1 \mathrm{H}, J=4.4 \mathrm{~Hz}), 4.03(\mathrm{~m}, 1 \mathrm{H}), 3.91-3.83(\mathrm{~m}, 3 \mathrm{H}), 3.52(\mathrm{~s}$, 2H), $3.48(\mathrm{~d}, 1 \mathrm{H}, J=4.8 \mathrm{~Hz}), 2.55(\mathrm{~m}, 1 \mathrm{H}), 2.21(\mathrm{~m}, 1 \mathrm{H}), 2.15(\mathrm{dd}, 1 \mathrm{H}, J=13.2,6.9 \mathrm{~Hz}), 2.06$ (ddd, $1 \mathrm{H}, J=12.2,12.2,9.3 \mathrm{~Hz}), 1.91(\mathrm{~m}, 3 \mathrm{H}), 1.78(\mathrm{~m}, 1 \mathrm{H}), 1.61(\mathrm{~s}, 3 \mathrm{H}), 1.55$ (dd, 1H, $J=13.7$, 13.7), $1.42(\mathrm{~m}, 2 \mathrm{H}), 1.12(\mathrm{~d}, 3 \mathrm{H}, J=7.3 \mathrm{~Hz}), 1.01(\mathrm{~m}, 6 \mathrm{H}), 0.95(\mathrm{t}, 3 \mathrm{H}, J=7.3 \mathrm{~Hz}){ }^{13} \mathbf{C}-\mathbf{N M R}(100$ $\left.\mathrm{MHz}, \mathrm{C}_{6} \mathrm{D}_{6}\right) \delta 169.94,166.64,139.45,121.55,120.71,84.02,81.39,77.33,72.99,70.10,61.03$, $53.48,52.49,47.11,46.99,46.80,46.09,44.52,40.64,34.55,30.32,27.22,22.66,18.75,14.18$, 13.69 FTIR (film) v 3394, 2924, 1669, 1558, 1457, 1375, 1328, 1284, 1162, 1085, 1046 HRMS(ES) Calc'd for $\mathrm{C}_{26} \mathrm{H}_{38} \mathrm{O}_{6}[\mathrm{M}+\mathrm{H}]:$ 447.2746; found 447.2742

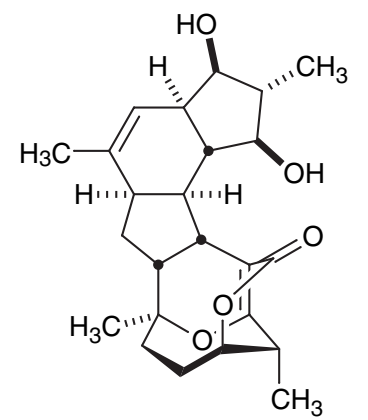

FR182877 (1) To a solution of ethyl ester $39(0.0030 \mathrm{~g}, 0.0067 \mathrm{mmol})$ in $1 \mathrm{~mL}$ of THF at $\mathrm{rt}$ was added TMSOK $(0.0048 \mathrm{~g}, 0.037 \mathrm{mmol})$ and the resulting solution was stirred for $12 \mathrm{~h}$. The reaction was then diluted to 5 $\mathrm{mL}$ with $0.1 \mathrm{M} \mathrm{NaHCO}_{3}$ and extracted with $2 \times 2 \mathrm{~mL}$ of $\mathrm{Et}_{2} \mathrm{O}$ and the organic layers were discarded. The aqueous layer was then acidified by the addition of $5 \mathrm{~mL}$ of $1 \mathrm{~N} \mathrm{HCl}$ and extracted with $3 \times 3 \mathrm{~mL}$ of $\mathrm{CH}_{2} \mathrm{Cl}_{2}$. The combined organic layers were then dried over $\mathrm{Na}_{2} \mathrm{SO}_{4}$. Evaporation in vacuo yielded a quantitative return of the FR182877 seco acid as a colorless amorphous solid. To a suspension of the FR182877 seco acid $(0.0010 \mathrm{~g}, 0.0025 \mathrm{mmol})$ in $2 \mathrm{~mL}$ of $\mathrm{CH}_{2} \mathrm{Cl}_{2}$ was added powdered $\mathrm{NaHCO}_{3}(0.0491 \mathrm{~g})$ and the mixture was degassed by 3 cycles of "freeze-pump-thaw." To the reaction was added Mukaiyama's reagent $(0.010 \mathrm{~g}, 0.039 \mathrm{mmol})$ and the yellow hetereogeneous mixture was vigorously stirred for $24 \mathrm{~h}$ then transferred directly to a silica gel column and purified by chromatography (100:1 EtOAc/MeOH) to give $0.00061 \mathrm{~g}(62 \%)$ of FR182877 as a white solid.

$\mathbf{R}_{\mathbf{f}}: 0.26(100: 1 \mathrm{EtOAc} / \mathrm{MeOH}) \quad[\alpha]_{\mathrm{D}}^{23}=-5^{\circ}(\mathrm{c}=0.15, \mathrm{MeOH}){ }^{1} \mathbf{H}-\mathbf{N M R}\left(500 \mathrm{MHz}, \mathrm{D}_{3} \mathrm{COD}\right) \delta$ $5.41(\mathrm{~s}, 1 \mathrm{H}), 4.43(\mathrm{~s}, 1 \mathrm{H}), 3.61 \mathrm{~d}, 1 \mathrm{H}, J=3.9 \mathrm{~Hz}), 3.46(\mathrm{~m}, 2 \mathrm{H}), 2.77(\mathrm{~m}, 1 \mathrm{H}), 2.65(\mathrm{t}, 1 \mathrm{H}, J=8.3$ Hz), 2.44 (m, 1H), 2.28 (dd, 1H, J=13.2, 8.3 Hz), 2.04 (dd, 1H, J=11.7, $6.9 \mathrm{~Hz}), 1.85$ (bd, 1H, $J=9.8 \mathrm{~Hz}), 1.83-1.73(\mathrm{~m}, 4 \mathrm{H}), 1.71(\mathrm{~s}, 3 \mathrm{H}), 1.66(\mathrm{~d}, 1 \mathrm{H}, J=3.9 \mathrm{~Hz}), 1.62-1.55(\mathrm{~m}, 2 \mathrm{H}), 1.40(\mathrm{~s}$, $3 \mathrm{H}), 1.12(\mathrm{~d}, 3 \mathrm{H}, J=7.4 \mathrm{~Hz}), 1.10(\mathrm{~d}, 3 \mathrm{H}, J=6.9 \mathrm{~Hz}){ }^{13} \mathbf{C}-\mathbf{N M R}\left(100 \mathrm{MHz}, \mathrm{D}_{3} \mathrm{COD}\right) \delta 172.9$, 168.7, 140.5, 121.2, 115.9, 88.6, 84.5, 79.3, 78.4, 54.6, 53.1, 52.4, 47.4, 46.9, 46.1, 43.4, 42.5, 36.2, 33.7, 25.2, 24.1, 22.9, 18.6, 9.4 FTIR (film) v 3420, 2925, 1704, 1624, 1457, 1366, 1269, 1212, 1018 HRMS(FAB) Calc'd for $\mathrm{C}_{24} \mathrm{H}_{32} \mathrm{O}_{5}[\mathrm{M}+\mathrm{H}]$ : 401.2328; found 401.2329 


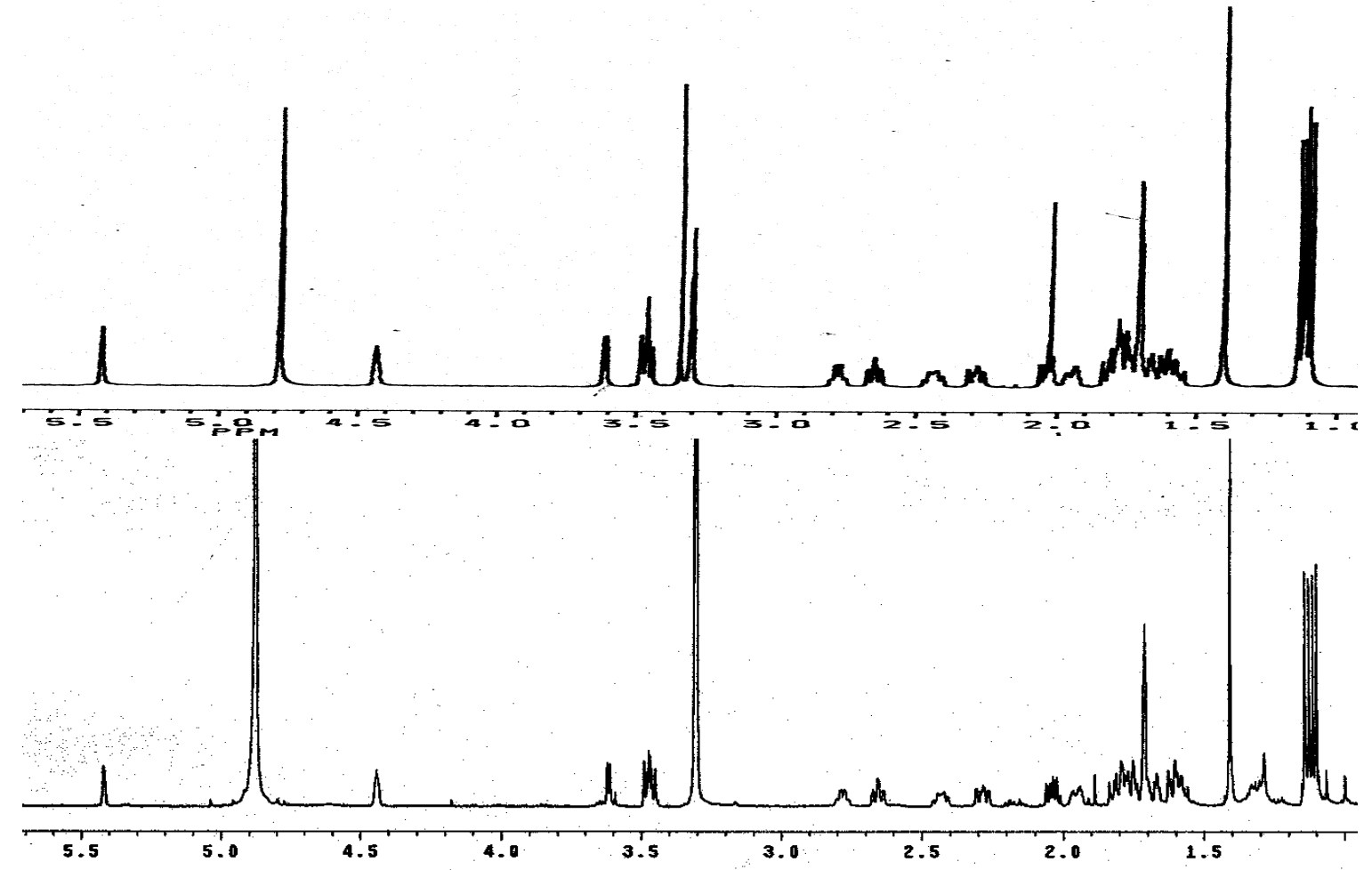

Figure 2. ${ }^{1} \mathrm{H}-\mathrm{NMR}$ comparison of natural FR182877 (top, $400 \mathrm{MHz} ; \mathrm{D}_{3} \mathrm{COD}$ ) and synthetic FR182877 (bottom, $500 \mathrm{MHz}$; $\mathrm{D}_{3} \mathrm{COD}$ ). Additional singlets at 3.3 and $2.0 \mathrm{ppm}$ in the spectrum of natural 1 are not recorded as part of the natural product structure by the authors of the original report.

Table 1. Tabular comparison of ${ }^{13} \mathrm{C}-\mathrm{NMR}$ data for natural and synthetic FR182877.

\begin{tabular}{c|c|c|} 
Carbon Number & S Natural (125 MHz; $\left.\mathrm{D}_{3} \mathrm{COD}\right)$ & S Synth. $\left(100 \mathrm{MHz} ; \mathrm{D}_{3} \mathrm{COD}\right)$ \\
\hline 1 & 172.9 & 172.9 \\
2 & 115.9 & 115.9 \\
3 & 43.4 & 43.4 \\
4 & 53.2 & 53.1 \\
5 & 46.2 & 46.1 \\
6 & 84.6 & 84.5 \\
7 & 54.6 & 54.6 \\
$7-\mathrm{Me}$ & 18.6 & 18.6 \\
8 & 78.4 & 79.3 \\
9 & 46.9 & 47.4 \\
10 & 121.2 & 121.2 \\
11 & 140.5 & 140.5 \\
$11-\mathrm{Me}$ & 22.7 & 22.9 \\
12 & 46.5 & 46.9 \\
13 & 33.3 & 33.7 \\
14 & 52.5 & 52.4 \\
15 & 87.7 & 88.6 \\
$15-\mathrm{Me}$ & 23.9 & 24.1 \\
17 & 167.7 & 168.7 \\
18 & 41.5 & 42.5 \\
$18-\mathrm{Me}$ & 9.3 & 9.4 \\
19 & 77.8 & 78.4 \\
20 & 24.4 & 25.2 \\
21 & 36.0 & 36.2 \\
\hline
\end{tabular}


Molecular Modeling. Tables 2 and 3 tabulate all computational data used for the "Transition State Approach Analysis." All calculations were performed at the PM3 level of theory using Spartan running on a SGI Indigo ${ }^{2}$. Geometry optimizations were performed under the following dihedral angle constraints: $\mathrm{O}$ (ester carbonyl) $=\mathrm{C} 1-\mathrm{C} 2=\mathrm{C} 3: 180^{\circ} ; \mathrm{C} 2=\mathrm{C} 3-\mathrm{C} 4=\mathrm{C} 5: 180^{\circ} ; \mathrm{C} 9=\mathrm{C} 10-$ $\mathrm{C} 11=\mathrm{C} 12: 0{ }^{\circ} \mathrm{C}$. "d $-\pi / \AA$ " indicates the constrained interatomic distances between $\mathrm{C} 5-\mathrm{C} 9$ and C4-C12 during individual geometry optimizations. "Endo-I" indicates the structures were optimized for a local minimum corresponding to the $\pi$-face alignment leading to the stereochemistry of the ABC ring fusion of 1. "Endo-II" indicates the structures were optimized for a local minimum corresponding to the $\pi$-face alignment leading to the opposite endo product (Figure 7). Notation of substitution and stereochemistry are as follows: "[18, 19][R, S, N]" where 18 or 19 refer to the substituted carbon number and $\mathrm{R}$ or $\mathrm{S}$ refer to the absolute configuration of the substitution and $\mathrm{N}$ indicates no substitution is present on that carbon. "IMDA" indicates data obtained for the acyclic intramolecular Diels-Alder control substrate (64). All data points are in $\mathrm{kcal} / \mathrm{mol}$.

Table 2

\begin{tabular}{c|cccccccccc}
\hline Endo-I & $\mathbf{5 3}$ & $\mathbf{5 6}$ & $\mathbf{5 7}$ & $\mathbf{5 4}$ & $\mathbf{5 5}$ & $\mathbf{6 0}$ & $\mathbf{5 9}$ & $\mathbf{5 8}$ & $\mathbf{6 1}$ & $\mathbf{6 4}$ \\
\hline \hline $\mathrm{d}-\boldsymbol{\pi} / \AA$ & $18 \mathrm{~N}, 19 \mathrm{~N}$ & $18 \mathrm{R}, 19 \mathrm{~N}$ & $18 \mathrm{~S}, 19 \mathrm{~N}$ & $18 \mathrm{~N}, 19 \mathrm{R}$ & $18 \mathrm{~N}, 19 \mathrm{~S}$ & $18 \mathrm{R}, 19 \mathrm{R}$ & $18 \mathrm{R}, 19 \mathrm{~S}$ & $18 \mathrm{~S}, 19 \mathrm{R}$ & $18 \mathrm{~S}, 19 \mathrm{~S}$ & IMDA \\
\hline 2.1 & -101.19 & -130.5 & -136.55 & -103.5 & -98.65 & -129.76 & -124.33 & -131.49 & -132.83 & -41.66 \\
2.3 & -106.35 & -135.41 & -140.85 & -108.1 & -101.84 & -134.94 & -129.33 & -136.45 & -136.38 & -46.21 \\
2.5 & -117.83 & -147.55 & -152.23 & -119.79 & -113.75 & -147.38 & -141.59 & -148.88 & -148.77 & -55.99 \\
2.7 & -125.9 & -156.61 & -159.89 & -128.23 & -120.54 & -156.8 & -150.93 & -158.05 & -156.2 & -63.06 \\
2.9 & -130.88 & -161.88 & -164.09 & -133.09 & -127.43 & -162.29 & -154.87 & -163.54 & -160.27 & -67.18 \\
\hline
\end{tabular}

Table 3

\begin{tabular}{c|cccccccccc}
\hline Endo-II & $\mathbf{5 3}$ & $\mathbf{5 6}$ & $\mathbf{5 7}$ & $\mathbf{5 4}$ & $\mathbf{5 5}$ & $\mathbf{6 0}$ & $\mathbf{5 9}$ & $\mathbf{5 8}$ & $\mathbf{6 1}$ & $\mathbf{6 4}$ \\
\hline \hline $\mathrm{d}-\pi / \AA$ & $18 \mathrm{~N}, 19 \mathrm{~N}$ & $18 \mathrm{R}, 19 \mathrm{~N}$ & $18 \mathrm{~S}, 19 \mathrm{~N}$ & $18 \mathrm{~N}, 19 \mathrm{R}$ & $18 \mathrm{~N}, 19 \mathrm{~S}$ & $18 \mathrm{R}, 19 \mathrm{R}$ & $18 \mathrm{R}, 19 \mathrm{~S}$ & $18 \mathrm{~S}, 19 \mathrm{R}$ & $18 \mathrm{~S}, 19 \mathrm{~S}$ & $\mathrm{IMDA}$ \\
\hline 2.1 & -102.33 & -136.97 & -131.02 & -98.82 & -104.1 & -132.85 & -133.46 & -124.56 & -129.28 & -41.83 \\
2.3 & -106.52 & -141.04 & -135.66 & -101.79 & -108.4 & -136.27 & -136.8 & -131.56 & -134.25 & -46.51 \\
2.5 & -118.22 & -152.58 & -147.81 & -113.82 & -120.24 & -148.28 & -150.13 & -139.52 & -146.74 & -56.22 \\
2.7 & -126.59 & -160.8 & -156.57 & -120.02 & -128.65 & -155.47 & -159.07 & -150.17 & -155.41 & -61.99 \\
2.9 & -131.38 & -165.21 & -161.72 & -125.47 & -133.57 & -160.2 & -164.25 & -157.83 & -159.79 & -66.72 \\
\hline
\end{tabular}

